Prepared in cooperation with Pikes Peak Area Council of Governments, Colorado Water Conservation Board, Colorado Springs City Engineering, and Lower Arkansas Valley Water Conservancy District

\title{
Prediction of Suspended-Sediment Concentrations at Selected Sites in the Fountain Creek Watershed, Colorado, 2008-09
}

Scientific Investigations Report 2012-5102 
Cover. The photograph was taken using a waterproof camera setting on the bed of Fountain Creek. The image shows grains of sand and gravel on the streambed of Fountain Creek and turbid streamflow caused by suspended sediment. Photograph was taken by Robert W. Stogner, U.S. Geological Survey. 


\section{Prediction of Suspended-Sediment Concentrations at Selected Sites in the Fountain Creek Watershed, Colorado, 2008-09}

By Robert W. Stogner, Sr., Jonathan M. Nelson, Richard R. McDonald, Paul J. Kinzel, and David P. Mau

Prepared in cooperation with Pikes Peak Area Council of Governments, Colorado Water Conservation Board, Colorado Springs City Engineering, and Lower Arkansas Valley Water Conservancy District

Scientific Investigations Report 2012-5102 


\section{U.S. Department of the Interior \\ KEN SALAZAR, Secretary \\ U.S. Geological Survey \\ Marcia K. McNutt, Director}

\section{U.S. Geological Survey, Reston, Virginia: 2013}

For more information on the USGS — the Federal source for science about the Earth, its natural and living resources, natural hazards, and the environment, visit http://www.usgs.gov or call 1-888-ASK-USGS.

For an overview of USGS information products, including maps, imagery, and publications, visit http://www.usgs.gov/pubprod

To order this and other USGS information products, visit http://store.usgs.gov

Any use of trade, firm, or product names is for descriptive purposes only and does not imply endorsement by the U.S. Government.

Although this information product, for the most part, is in the public domain, it also may contain copyrighted materials as noted in the text. Permission to reproduce copyrighted items must be secured from the copyright owner.

Suggested citation:

Stogner, R.W., Sr., Nelson, J.M., McDonald, R.R., Kinzel, P.J., and Mau, D.P., 2013, Prediction of suspended-sediment concentrations at selected sites in the Fountain Creek watershed, Colorado, 2008-09: U.S. Geological Survey Scientific Investigations Report 2012-5102, 36 p. 


\section{Contents}

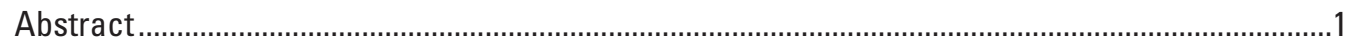

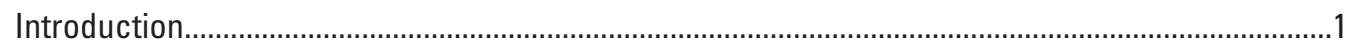

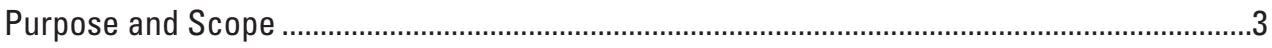

Description of Fountain Creek Watershed ..................................................................................

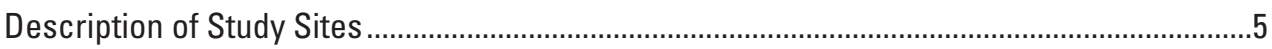

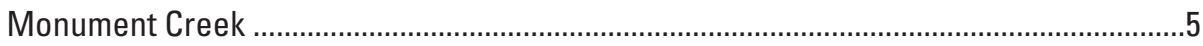

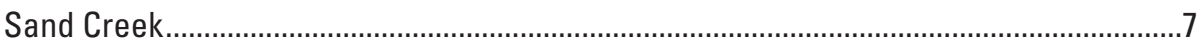

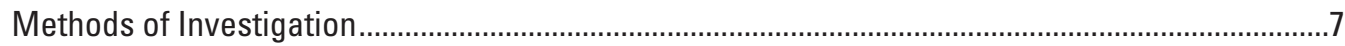

Measurement of Stream Stage, Velocity, and Discharge ...........................................................

Measurements of Channel Topography.......................................................................................

Measurement of Suspended-Sediment Concentration and Particle Size ................................

Measurement of Bed-Material Particle Size ................................................................................9

Computational Methods for Flow and Suspended Sediment..................................................10

Suspended-Sediment Modeling ...................................................................................................10

Rouse Method with Smith/McLean Reference Concentration .........................................10

Rouse Method with Reference Concentration Equation Calibrated with Field Data .....11

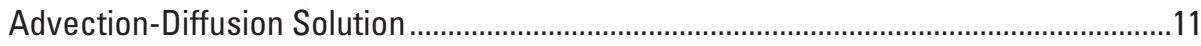

Statistical Analysis ........................................................................................................... 11

Flow and Suspended-Sediment Model Development ................................................................11

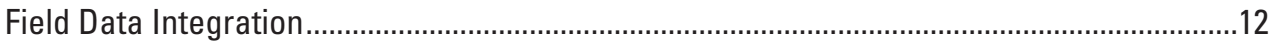

Bed Material Particle-Size Data ...............................................................................12

Suspended-Sediment Data .....................................................................................

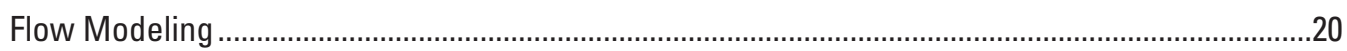

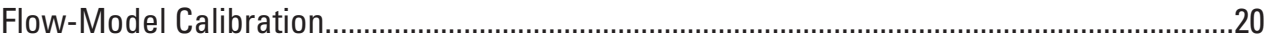

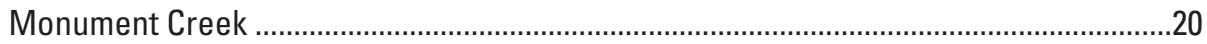

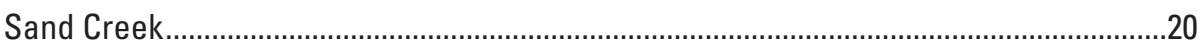

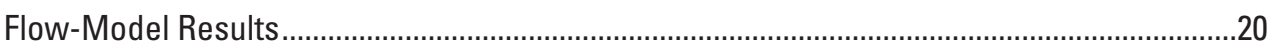

Predicted Suspended-Sediment Concentrations ............................................................................23

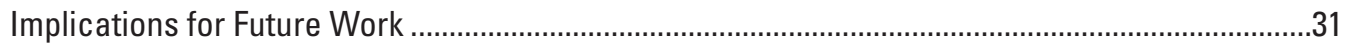

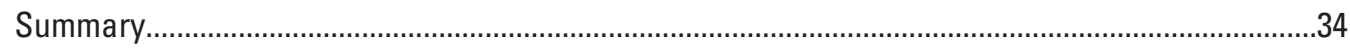

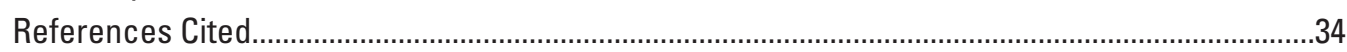

\section{Figures}

1. Location and generalized surficial geology of the Fountain Creek watershed and general location of Palmer Divide, Colorado

2. Annual hydrograph of mean-daily streamflow at selected locations in the Fountain Creek watershed, Colorado

3. Location of the Monument Creek study site in the vicinity of Monument Creek near Woodmen Road (U.S. Geological Survey (USGS) site 07103970) with location of benchmarks, reference points, transducers, auto-sampler intakes, and survey points 
4. Location of the Sand Creek study site in the vicinity of Sand Creek near Las Vegas Street (U.S. Geological Survey (USGS) site 07105600) with location of benchmarks, reference points, transducers, auto-sampler intakes, and survey points. 8

5. Particle-size distribution data for bed-sediment samples collected in Monument Creek near U.S. Geological Survey gage site 07103970. (Sampling locations are shown in figure 3.)

6. Particle-size distribution data for bed-sediment samples collected in Sand Creek near U.S. Geological Survey gage site 07105600 . (Sampling locations are shown in figure 4.).

7. Particle-size distribution for bed sediments for composite of all samples collected in Monument Creek near U.S. Geological Survey gage site 07103970 and Sand Creek near U.S. Geological Survey gage site 07105600. 15

8. Streamflow, suspended-sediment, and sand concentrations in samples collected from the Monument Creek site during August 2008 16

9. Particle-size distribution data for suspended-sediment samples collected at a single point in the vertical in Monument Creek near U.S. Geological Survey gage site 07103970 (location is shown in figure 3 ).

10. Particle-size distribution data for suspended-sediment samples collected at a single point in the vertical in Sand Creek near U.S. Geological Survey gage site 07105600 (location is shown in figure 4).

11. Measured suspended-sediment concentrations of samples collected at a single vertical location in Monument Creek near U.S. Geological Survey gage site 07103970 as a function of streamflow

12. Measured suspended-sediment concentrations of samples collected at a single vertical location in Sand Creek near U.S. Geological Survey gage site 07105600 as a function of streamflow

13. Root-mean-squared error between the measured and predicted water-surface elevation as a function of roughness at $(A)$ the upper Monument Creek reach and $(B)$ the lower Monument Creek reach

14. Measured and predicted water surface as a function of streamwise distance in the downstream direction for the calibrated value of roughness at $(A)$ the upper Monument Creek reach and $(B)$ the lower Monument Creek reach

15. Predicted stream velocities in the upper Monument Creek study reach at $(A) 2.52$ cubic meters per second and $(B) 11.52$ cubic meters per second.

16. Predicted bed shear stress at the upper Monument Creek study reach at $(A) 2.52$ cubic meters per second and $(B) 11.52$ cubic meters per second.

17. The measured suspended-sediment concentrations in the $(A)$ upper reach of the Monument Creek site and $(B)$ lower reach of the Monument Creek site ..... .26

18. Predicted sand concentration at the $(A)$ upper reach of the Monument Creek site using the average calibrated gamma $(0.003)$ from the lower reach and $(B)$ lower reach of the Monument Creek site using the average calibrated gamma (0.0035) from the upper reach

19. Mean suspended-sand concentrations at the upper Monument Creek reach for $(A)$ a storm-flow event at 2.52 cubic meters per second and ( $B$ ) a stormflow event at 11.52 cubic meters per second

20. Suspended-sand load computed at each section in the modeling domain for the upper Monument Creek reach for two sampled storm-flow events. 
21. Total load computed at each section in the modeling domain for the upper Monument Creek reach for two sampled storm-flow events ..

22. The measured and predicted sand fraction as a function of particle size for each of two sampled storm events...

23. (A) The measured total suspended-sediment concentration using the Equal Width Increment (EWI) method for all samples collected at the upper Monument Creek reach from 2001-08 and the mean predicted suspended-sand concentration (particle-size distributions 1-5), and (B) Particle-size fractions for the predicted particle-size distributions $1-4$ described in $(A)$

\section{Tables}

1. Suspended-sediment analyses and size fraction data provided by each analysis.........10

2. Calculated gamma for each measured sand concentration in the upper subreach of the Monument Creek site......................................................................................27

3. Calculated gamma for each measured sand concentration in the lower subreach

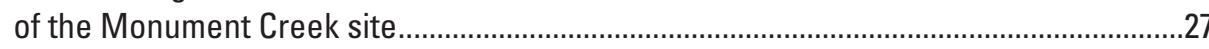




\section{Conversion Factors}

SI to Inch/Pound

\begin{tabular}{lcl}
\hline \multicolumn{1}{c}{ Multiply } & By & \multicolumn{1}{c}{ To obtain } \\
\hline centimeter $(\mathrm{cm})$ & Length & \\
millimeter $(\mathrm{mm})$ & 0.3937 & inch (in.) \\
micron $(\mathrm{mm})$ & 0.03937 & inch (in.) \\
meter $(\mathrm{m})$ & 0.00003937 & inch (in.) \\
\hline & 3.281 & foot $(\mathrm{ft})$ \\
\hline square kilometer $\left(\mathrm{km}^{2}\right)$ & Area & \\
square meter $\left(\mathrm{m}^{2}\right)$ & 0.3861 & square mile $\left(\mathrm{mi}^{2}\right)$ \\
square meter $\left(\mathrm{m}^{2}\right)$ & 0.0002471 & acre \\
\hline & 10.76 & square foot $\left(\mathrm{ft}^{2}\right)$ \\
\hline cubic meter $\left(\mathrm{m}^{3}\right)$ & Volume & gallon $(\mathrm{gal})$ \\
cubic meter $\left(\mathrm{m}^{3}\right)$ & 264.2 & cubic foot $\left(\mathrm{ft}^{3}\right)$ \\
milliliter $(\mathrm{mL})$ & 35.31 & ounce $(\mathrm{fl} . \mathrm{oz})$ \\
\hline & 0.03381 & \\
\hline meter per second $(\mathrm{m} / \mathrm{s})$ & Flow rate & foot per second $(\mathrm{ft} / \mathrm{s})$ \\
cubic meter per second $\left(\mathrm{m}^{3} / \mathrm{s}\right)$ & 3.281 & acre-foot per day $(\mathrm{acre}-\mathrm{ft} / \mathrm{d})$ \\
cubic meter per second $\left(\mathrm{m}^{3} / \mathrm{s}\right)$ & 70.07 & cubic foot per second $\left(\mathrm{ft}^{3} / \mathrm{s}\right)$ \\
\hline
\end{tabular}

Pressure: 1 Pascal $(\mathrm{Pa})=1$ Newton $(\mathrm{N}) / \mathrm{m}^{2}$

6.895 kilopascals $(\mathrm{kPa})=1$ pound per square inch

Temperature in degrees Celsius $\left({ }^{\circ} \mathrm{C}\right)$ may be converted to degrees Fahrenheit $\left({ }^{\circ} \mathrm{F}\right)$ as follows:

${ }^{\circ} \mathrm{F}=\left(1.8 \times{ }^{\circ} \mathrm{C}\right)+32$

Temperature in degrees Fahrenheit $\left({ }^{\circ} \mathrm{F}\right)$ may be converted to degrees Celsius $\left({ }^{\circ} \mathrm{C}\right)$ as follows:

${ }^{\circ} \mathrm{C}=\left({ }^{\circ} \mathrm{F}-32\right) / 1.8$

Vertical coordinate information is referenced to the "North American Vertical Datum of 1988 (NAVD 88)"

Horizontal coordinate information is referenced to the "North American Datum of 1983 (NAD 83)"

Elevation, as used in this report, refers to distance above the vertical datum.

Specific conductance is given in microsiemens per centimeter at 25 degrees Celsius $(\mu \mathrm{S} / \mathrm{cm}$ at $\left.25^{\circ} \mathrm{C}\right)$.

Concentrations of chemical constituents in water are given either in milligrams per liter (mg/L) or micrograms per liter ( $\mu \mathrm{g} / \mathrm{L})$. 


\section{Abbreviations and acronyms used in this report}

$\begin{array}{ll}\text { DCP } & \text { data collection platform } \\ \text { EWI } & \text { equal-width increment } \\ \text { FaSTMECH } & \text { Flow and Sediment Transport with Morphologic Evolution of Channels } \\ \text { GCS } & \text { grade-control structure } \\ \text { GPS } & \text { Global Positioning System } \\ \text { MD-SWMS } & \text { Multi-Dimensional Surface-Water Modeling System } \\ \text { RMSE } & \text { root mean squared error } \\ \text { RTK } & \text { real-time kinematic } \\ \text { USGS } & \text { U.S. Geological Survey }\end{array}$





\title{
Prediction of Suspended-Sediment Concentrations at Selected Sites in the Fountain Creek Watershed, Colorado, 2008-09
}

\author{
By Robert W. Stogner, Sr., Jonathan M. Nelson, Richard R. McDonald, Paul J. Kinzel, and David P. Mau
}

\section{Abstract}

In 2008, the U.S. Geological Survey (USGS), in cooperation with Pikes Peak Area Council of Governments, Colorado Water Conservation Board, Colorado Springs City Engineering, and the Lower Arkansas Valley Water Conservancy District, began a small-scale pilot study to evaluate the effectiveness of the use of a computational model of streamflow and suspended-sediment transport for predicting suspendedsediment concentrations and loads in the Fountain Creek watershed in Colorado. Increased erosion and sedimentation damage have been identified by the Fountain Creek Watershed Plan as key problems within the watershed. A recommendation in the Fountain Creek Watershed plan for management of the basin is to establish measurable criteria to determine if progress in reducing erosion and sedimentation damage is being made. The major objective of this study was to test a computational method to predict local suspended-sediment loads at two sites with different geomorphic characteristics in order to evaluate the feasibility of using such an approach to predict local suspended-sediment loads throughout the entire watershed. Detailed topographic surveys, particle-size data, and suspended-sediment samples were collected at two gaged sites: Monument Creek above Woodmen Road at Colorado Springs, Colorado (USGS gage 07103970), and Sand Creek above mouth at Colorado Springs, Colorado (USGS gage 07105600). These data were used to construct three-dimensional computational models of relatively short channel reaches at each site. The streamflow component of these models predicted a spatially distributed field of water-surface elevation, water velocity, and bed shear stress for a range of stream discharges. Using the model predictions, along with measured particle sizes, the sediment-transport component of the model predicted the suspended-sediment concentration throughout the reach of interest. These computed concentrations were used with predicted flow patterns and channel morphology to determine fluxes of suspended sediment for the median particle size and for the measured range of particle sizes in the channel. Three different techniques were investigated for making the suspended-sediment predictions; these techniques have varying degrees of reliance on measured data and also have greatly differing degrees of complexity. Based on these data, the calibrated Rouse method provided the best balance between accuracy and both computational and data collection costs; the presence of substantial washload was the primary factor in eliminating the simpler and the more complex techniques. Based on this work, using the selected technique at additional sites in the watershed to determine relative loads and source areas appears plausible. However, to ensure that the methodology presented in this report yields reasonable results at other selected sites in the basin, it is necessary to collect additional verification data sets at those locations.

\section{Introduction}

The Fountain Creek watershed drainage network currently is a highly dynamic system arising from (1) the potential for very high rainfall rates (orographic induced along the Palmer Divide and the Rampart Range (fig. 1) (Doesken and others, 2003; Meister, 2010), (2) easily eroded alluvium along the valley bottoms east of the foothills (Fountain Creek Watershed Flood Control and Greenway District, 2011), and (3) very rapid urban development. Very rapid urban development has the potential to exacerbate the rainfall runoff rates, increase storm runoff peaks, and undermine the natural geomorphic protections against uncontrolled incision provided by bed armoring and floodplain vegetation and the resulting sedimentation in the lower reaches of the watershed (Fountain Creek Watershed Flood Control and Greenway District, 2011).

The Fountain Creek Watershed Plan (U.S. Army Corps of Engineers, 2009) identified both erosion and sedimentation as key issues in the watershed. The plan also recommended the development of measureable criteria to evaluate both the magnitude of erosion in the watershed and the effectiveness of management actions to reduce erosion. Therefore a thorough evaluation of sediment transport mass balance throughout the stream network was important. Such an evaluation required examining both of the fundamental modes of sediment transport, namely bedload and suspended load (Middleton and Southard, 1984). Bedload transport in Fountain Creek has been studied in detail (U.S. Army Corps of Engineers, 2009). 


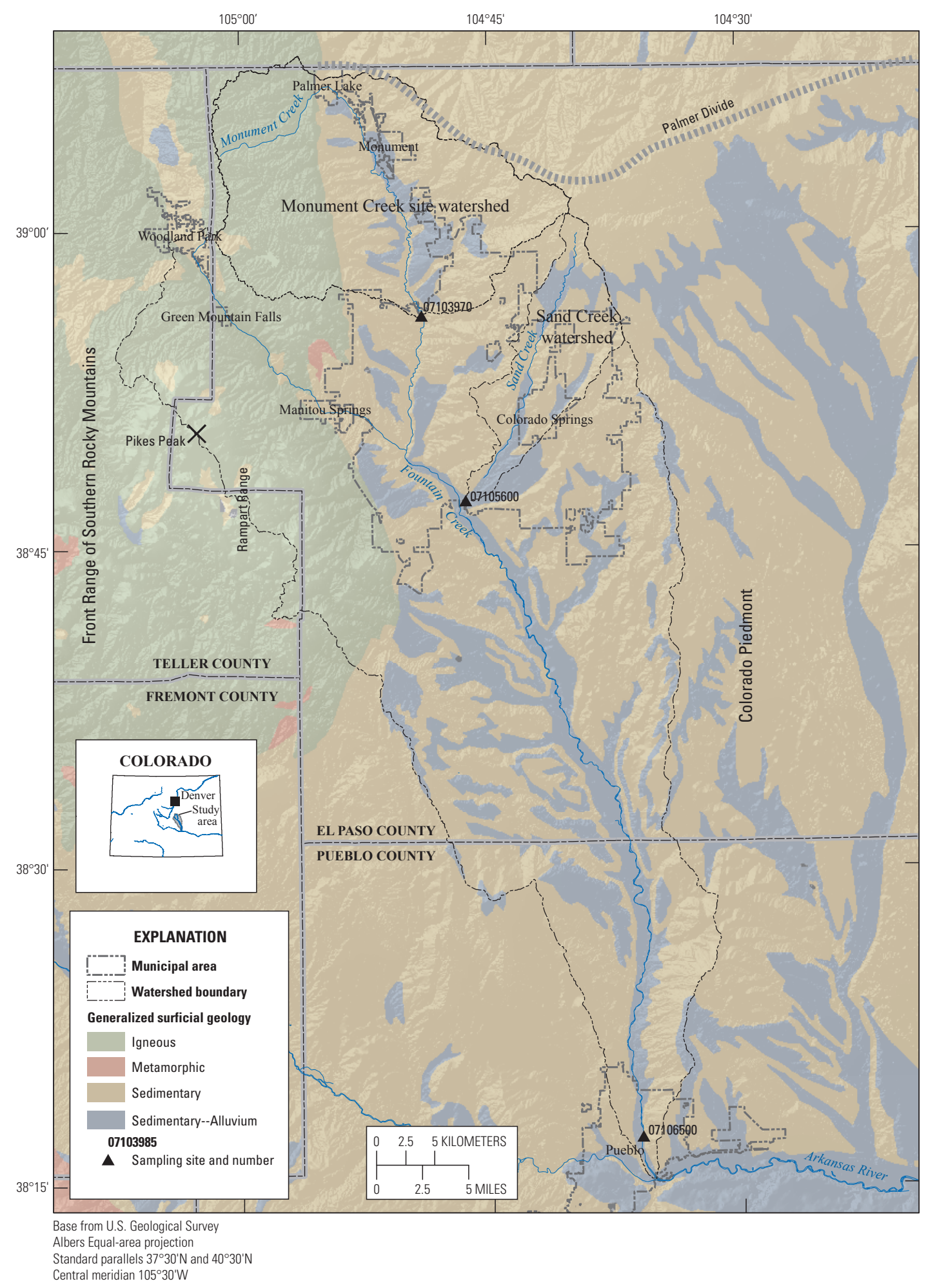

Figure 1. Location and generalized surficial geology of the Fountain Creek watershed and general location of Palmer Divide, Colorado. 
In contrast, relatively little work has been done to evaluate the transport of suspended sediment throughout the watershed by particle-size range despite the fact that parts of the Fountain Creek network have the potential to export large volumes of suspended sediment, including sand-size particles, during high flows.

The most reliable way to determine the dominant sources of water in a drainage network for particular rainfall events is to gage the water discharge, hereafter referred to as "streamflow," in that network densely and accurately. Similarly, the most reliable way to determine the sources of various types and sizes of sediment in a drainage network is to gage suspended-sediment discharge, hereafter referred to as "sediment-transport rate," in that network densely and accurately. Unfortunately, in a complex watershed like Fountain Creek, this field-based methodology is relatively time consuming and expensive. Thus, the high cost of making suspendedsediment measurements has been a barrier to addressing this dominant component of the sediment transport problem in the Fountain Creek watershed. However, models of flow and suspended-sediment transport applied at critical reaches using detailed local data, when used together with a relatively small set of field measurements of suspended-sediment transport, offer a less expensive alternative to detailed field data collection efforts that would be required to directly gage suspendedsediment transport. These models can potentially predict both flow patterns and sediment fluxes based on measured topography and particle sizes of bed material and suspended sediment. Using this technique at several locations would provide spatial information about the relative contributions of different source areas and provide a sediment load for various tributaries.

In 2008, the U.S. Geological Survey (USGS), in cooperation with Pikes Peak Area Council of Governments, Colorado Water Conservation Board, Colorado Springs City Engineering, and the Lower Arkansas Valley Water Conservancy District, began a small-scale pilot study to evaluate the effectiveness of the use of a computational model of flow and suspended-sediment transport for predicting suspended-sediment concentrations and loads in the Fountain Creek watershed in southeastern Colorado.

\section{Purpose and Scope}

The purpose of this report is to present the results of a pilot study to develop, calibrate, and validate a multidimensional model as an inexpensive tool to predict suspendedsediment concentrations and to calculate suspended-sediment loads at various locations within the Fountain Creek watershed in southeastern Colorado. Two sites with different geomorphic characteristics were selected, and three different suspendedsediment transport techniques were evaluated in order to assess the feasibility of using these techniques to predict local suspended-sediment loads throughout the watershed as a lower cost alternative to traditional gaging methods. This report describes (1) data requirements of the hydraulic and sediment transport models, (2) data collection methods, (3) hydraulic and sediment transport model calibration, and (4) an evaluation of each of the three techniques for predicting suspended-sediment concentrations at the two sites. Comparisons of accuracy and cost associated with each technique provide information that can be used to select a methodology that best fits suspended-sediment monitoring objectives within the Fountain Creek watershed. Ideally, this will lead to the application of a singular method on a watershed-wide selection of sites.

\section{Description of Fountain Creek Watershed}

The Fountain Creek watershed, in and along the eastern slope of the Front Range section of the southern Rocky Mountains, drains approximately 2,410 square kilometers $\left(\mathrm{km}^{2}\right)$ of parts of Teller, El Paso, and Pueblo Counties in eastern Colorado (fig. 1). Land-surface elevation ranges from 4,300 meters (m) at the summit of Pikes Peak to 1,414 m at the confluence of Fountain Creek and the Arkansas River. Surficial geology is dominated by various igneous rock units within the Rampart Range and by various sedimentary rock units in the Colorado Piedmont. More detailed geologic and soil information is available in Larsen (1981), von Guerard (1989), and U.S. Army Corps of Engineers (2009).

Streamflow can vary hourly, daily, and seasonally and is driven by several natural and anthropogenic processes. Snowmelt runoff from the Rampart Range generally occurs between mid-April and mid-June (Stogner, 2000) and is characterized by diurnal variations in streamflow in response to cycles of heating and cooling over the course of a day. Duration and magnitude of snowmelt runoff varies annually depending on extent and depth of winter and spring snowfall and on the rate of spring heating. Storm runoff generally occurs between mid-June and early October and is characterized by rapid increases in streamflow in response to afternoon and evening convectional storms. Duration and magnitude of storm runoff varies depending on extent, intensity, and duration of storms. Flashfloods are common during summer storms and can produce extreme changes in stream-channel geometry. Water use and water management cause hourly, daily, and seasonal changes in streamflow through importation of nonnative water, increased return flows from increased water use, water diversions, wastewater-treatment-plant discharges, and changes in water management and operations (Stogner, 2000). Figure 2 shows mean-daily streamflow for U.S. Geological Survey (USGS) streamflow gage 07106500 (Fountain Creek at Pueblo, Colo.) near the confluence with the Arkansas River. The hydrograph represents the annual streamflow characteristics for the Fountain Creek watershed, which is dominated by spring snowmelt and summer stormflow.

Land use within the Fountain Creek watershed has substantially changed since 1900 as a result of increased population. The population of El Paso County was approximately 31,600 in 1900 , approximately 74,500 in 1950, and 

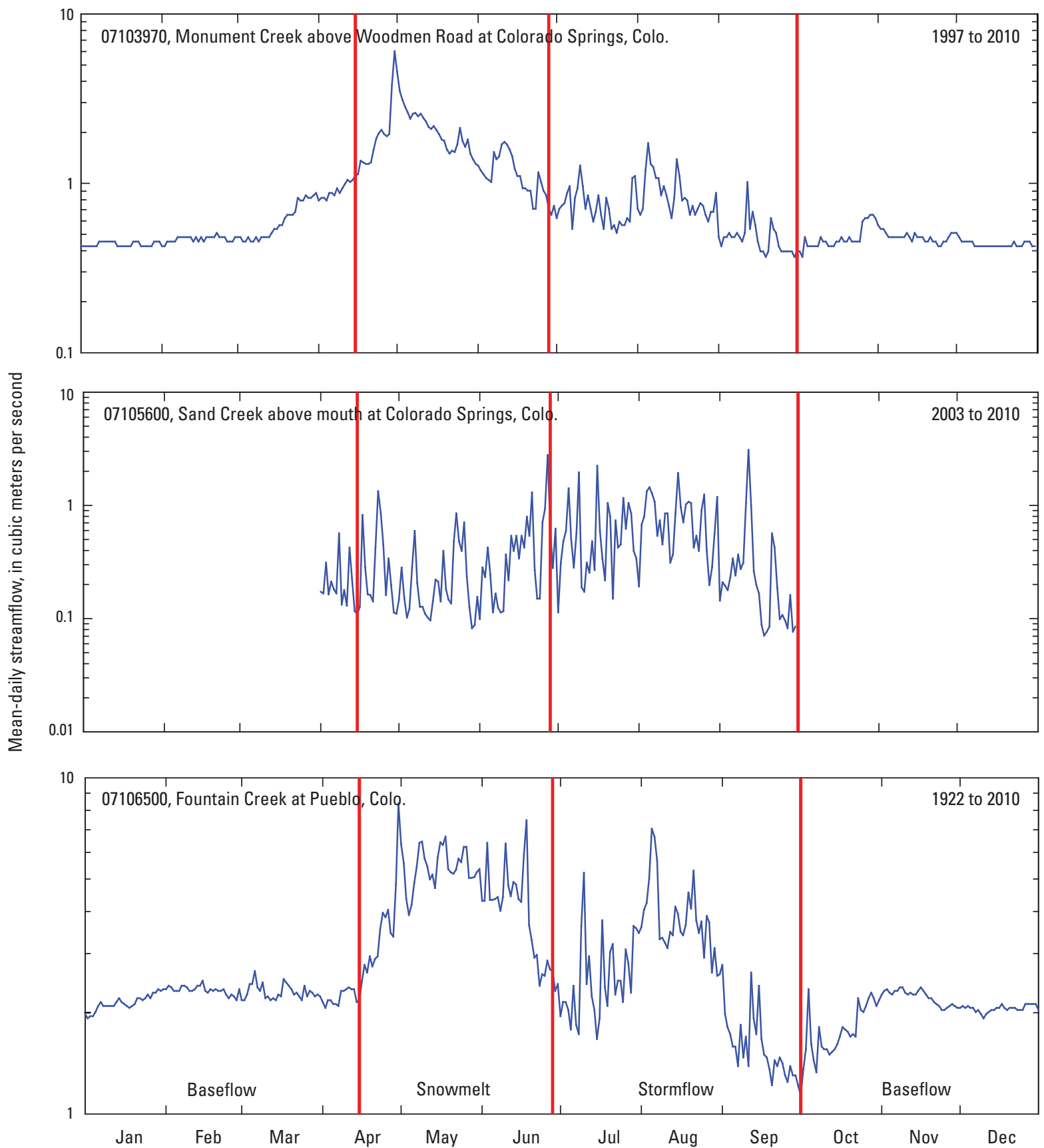

Figure 2. Annual hydrograph of mean-daily streamflow at selected locations in the Fountain Creek watershed, Colorado. 
approximately 517,000 in 2000 (U.S. Census Bureau, 2010a; U.S. Census Bureau, 2010b). As population increased, changes in land use have facilitated additional changes in streamflow characteristics, specifically through urbanization and increased impervious land cover (Stogner, 2000). Estimated impervious land cover in El Paso County increased by approximately 10 percent between 1997 and 2001 and by approximately 6 percent between 2001 and 2005 (Mau and others, 2007). During this time, the population of El Paso County increased by about 3 percent annually (Mau and others, 2007). Initial effects on streamflow characteristics may be subtle, but as the percentage of impervious land cover increases with time, substantial change can occur in storm-runoff timing and intensity resulting in larger peak streamflows (Dunne and Leopold, 1978).

Streambed and streambank material within Fountain Creek and its tributaries is predominantly sand- and gravelsize (0.0623-64 millimeters $(\mathrm{mm})$ ) alluvium, with some materials that are cobble- and boulder-size (greater than $64 \mathrm{~mm}$ ) in the upland and mountainous reaches. Minimum streamflows in Fountain Creek and its tributaries have the capacity to transport sand-size particles; higher streamflows ranging from 0.28 cubic meters per second $\left(\mathrm{m}^{3} / \mathrm{s}\right)$ to $17 \mathrm{~m}^{3} / \mathrm{s}$ have the capacity to transport gravel-size particles (Mau and others, 2007). Erosion and sedimentation within the Fountain Creek watershed can contribute to financial losses associated with damage to public and private property, as well as to transportation and municipal infrastructure near Fountain Creek and its tributaries.

\section{Description of Study Sites}

Two sites with different geomorphic characteristics were selected within the Fountain Creek watershed to provide case examples of typical stream types within the system. Selection of the field sites was based on availability of historical streamflow and sediment data, and site characteristics represented by streams originating in the Rampart Range and Colorado Piedmont. Monument Creek above Woodmen Road, USGS site 07103970 (hereafter referred to as "the Monument Creek site"), was selected to represent the streams originating in the Rampart Range. This site is dominated by snowmelt runoff (figs. 1 and 2). Sand Creek near the confluence with Fountain Creek, USGS site 07105600 (hereafter referred to as "the Sand Creek site"), was selected to represent the streams originating in the Colorado Piedmont. This site is dominated by storm runoff (figs. 1 and 2).

\section{Monument Creek}

Monument Creek, a major tributary to Fountain Creek, originates in the northwestern part of the Fountain Creek watershed in the Rampart Range. The creek flows northeasterly toward the community of Palmer Lake and then southernly through the city of Colorado Springs to the confluence with Fountain Creek. The Monument Creek watershed above USGS site 07103970 (fig. 1) encompasses about $469 \mathrm{~km}^{2}$
(U.S. Geological Survey, 2012a). Land use in 2005 was predominantly undeveloped (45.8 percent), residential (19.0 percent), and military (16.0 percent) (Mau and others, 2007). Mau and others (2007) estimated that 11.3 percent of land in the watershed was impervious to precipitation.

Monument Creek is a perennial stream with a singlethread, meandering channel with eroded banks (cutbanks) and point bars. The cutbanks expose fine sediments and mixtures of relatively fine sands with coarser gravels. The channel cross section is typically incised (Pikes Peak Area Council of Governments, 2009) with floodplains and terraces covered in grasses and woody vegetation. The riparian area varies in width from about 30 to $120 \mathrm{~m}$ within the rural corridor and is generally constrained by natural terraces. Upper terraces generally are not immediately impacted by urban or rural encroachment. Within the urban corridor of Colorado Springs, the riparian area adjacent to Monument Creek generally is narrower and constrained by natural terraces or concrete floodretaining walls. Urban development often extends to margins created by the concrete walls.

Data collection locations at the Monument Creek site are shown in figure 3 . The site is divided into an upper and a lower subreach by a concrete grade-control structure (GCS). The upper subreach is about $240 \mathrm{~m}$ in length and has a gradient of about 0.0048 . The USGS streamflow gage at the Monument Creek site is located on the right bank near the GCS. The site was instrumented with a Sutron Accububble and Sutron Model 8210 Data Collection Platform (DCP) to measure and record height of water surface above an established datum plane, hereafter referred to as "stage," and an ISCO Model 3700 automatic pumping sampler, hereafter referred to as an "autosampler," to collect water samples for analysis of suspended-sediment concentration. The intake tubing for the ISCO autosampler at this site has an internal diameter of $9.53 \mathrm{~mm}$, is about $10-\mathrm{m}$ long, and generally slopes downward toward the stream for the entire length of the tubing, toward the right bank. The riparian area of the upper subreach has a relatively wide floodplain constrained by natural terraces and some urban development. Below the GCS, the bed elevation decreased by approximately $1 \mathrm{~m}$. The lower subreach is about $250 \mathrm{~m}$ in length and has a gradient of about 0.0037 . A gage station was installed on the left bank at the terminus of the reach and was instrumented in a similar manner with respect to the upper reach. The intake tubing for the ISCO autosampler at this site has an internal diameter of $9.53 \mathrm{~mm}$, is about $3 \mathrm{~m}$ long, and generally slopes downward toward the stream for the entire length of the tubing; the intake is about $0.5 \mathrm{~m}$ from the left bank. The lower subreach is constrained by natural terraces through much of its length, transitioning to concrete flood walls and a narrow riparian area at the terminus of the reach. Tubing intakes were located at a fixed point in the water column. Bed material at the Monument Creek site is dominated by particles in the sand- and gravel-size fraction (0.0623-64 mm); however, bed scour within the upper subreach may seasonally expose the underlying bedrock. 


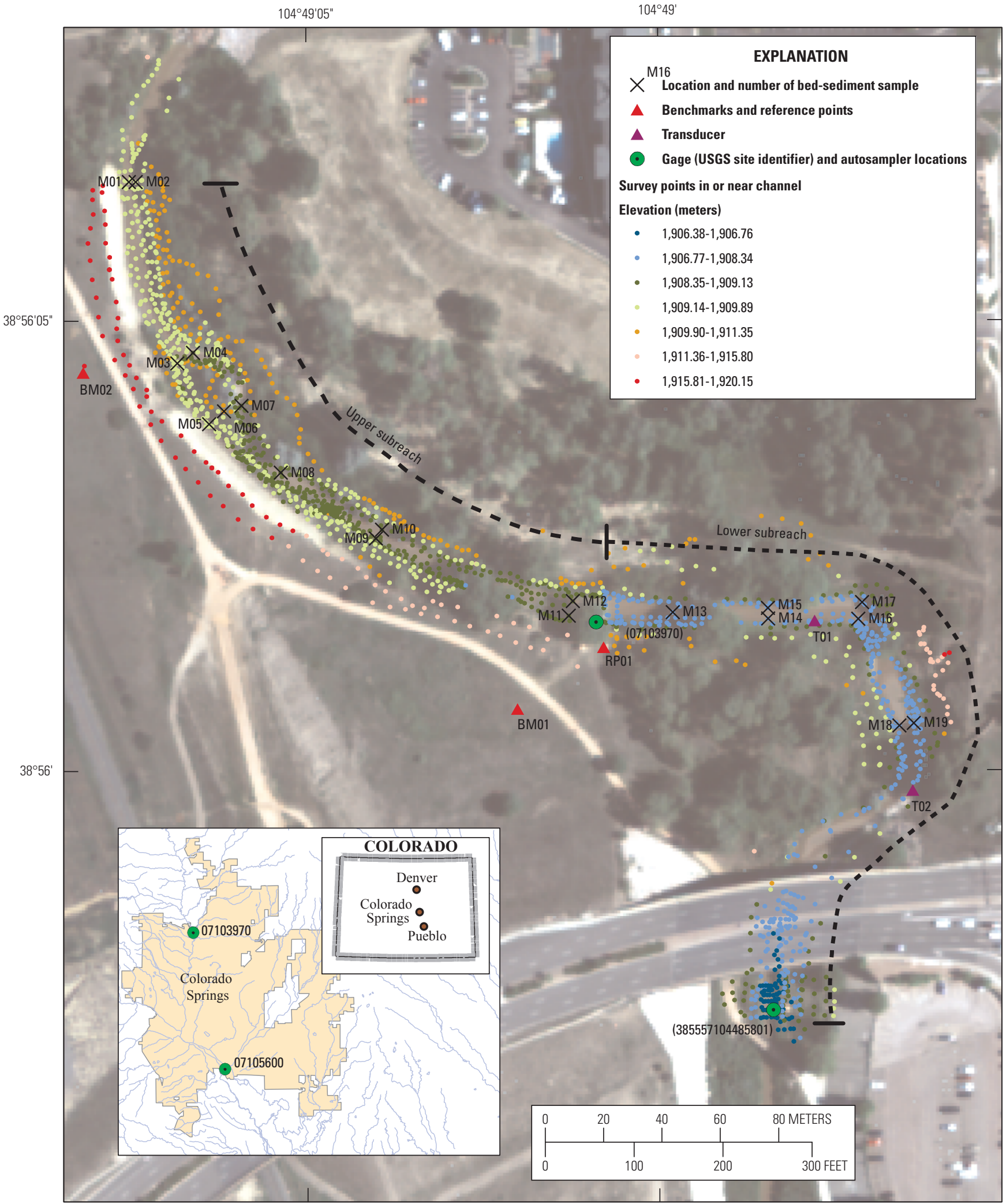

Imagery: USGS orthophotography, 1-meter pixels, 2011 photography. Projection: UTM zone 13, North American Datum of 1983

Figure 3. Location of the Monument Creek study site in the vicinity of Monument Creek near Woodmen Road (U.S. Geological Survey (USGS) site 07103970) with location of benchmarks, reference points, transducers, auto-sampler intakes, and survey points. 


\section{Sand Creek}

Sand Creek, a tributary to Fountain Creek, originates in the northeastern part of the Fountain Creek watershed. The creek flows southwesterly through the city of Colorado Springs to the confluence with Fountain Creek. The Sand Creek watershed above USGS site 07105600 (fig. 1) encompasses about $136 \mathrm{~km}^{2}$ (U.S. Geological Survey, 2012b). Land use in 2005 was predominantly agriculture (34.0 percent), undeveloped (18.9 percent), residential (25.9 percent), and commercial (4.9 percent) (Mau and others, 2007). Mau and others (2007) estimated that 10.9 percent of land in the watershed was impervious to precipitation. Sand Creek has been identified as one of the largest contributors of sediment load to Fountain Creek (von Guerard, 1989; U.S. Army Corps of Engineers, 2009).

Sand Creek is an ephemeral, braided stream that is sand material dominated. The channel cross section is approximately trapezoidal with rip-rapped banks interspersed with grasses and woody vegetation (Pikes Peak Area Council of Governments, 2009). The riparian area adjacent to Sand Creek is narrow, less than $30 \mathrm{~m}$, through most of the urban corridor due to channelization, channel widening, and (or) channel constriction associated with urban encroachment. Transportation, sewer, and utility infrastructure at several Sand Creek crossings are considered threatened due to lateral migration or downcutting (U.S. Army Corps of Engineers, 2009). Upper terraces generally are developed for commercial, industrial, or residential uses.

Data location of the Sand Creek site are shown in figure 4. The site is divided into an upper and a lower subreach by a concrete GCS. The upper subreach is about $150 \mathrm{~m}$ in length and has a gradient of about 0.0097 . The USGS streamflow gage at the Sand Creek site is located on the left bank near the GCS. The site was instrumented with a Sutron Accububble and Sutron Model 8210 DCP to measure and record stage and an ISCO Model 3700 autosampler to collect water samples for analysis of suspended-sediment concentration. The intake tubing for the ISCO autosampler at this site had an internal diameter of $9.53 \mathrm{~mm}$, was about $25 \mathrm{~m}$ long, and initially sloped downward toward the stream. However, approximately $13 \mathrm{~m}$ of tubing lies relatively flat across the top of the GCS before opening near mid-channel. Below the GCS, the bed elevation decreased by approximately $0.2 \mathrm{~m}$. The lower subreach is about $280 \mathrm{~m}$ in length and has a gradient of about 0.0098 . A gage station was installed at the terminus of the reach and similarly instrumented with a Sutron Accububble and Model 8200A DCP to measure and record stream stage and an ISCO Model 3700 autosampler to collect water samples for analysis of suspended-sediment concentration. The intake tubing for the ISCO autosampler at this site is about $10 \mathrm{~m}$ long and slopes downward toward the stream for the entire length of the tubing; the intake is approximately $2 \mathrm{~m}$ streamward of the left bank. Tubing intakes at Sand Creek were located at a fixed point in the water column. The riparian area is narrow and constrained by rip-rapped terraces. Bed material is dominated by particles in the sand- and gravel-size fraction $(0.0623-$ $64 \mathrm{~mm})$.

\section{Methods of Investigation}

Field work at the two sites consisted of continuation of existing USGS streamflow-gaging-station operations as well as data collection specifically needed for model application and verification. Initial geomorphic surveys, including channel topography, water-surface elevations, and bed-material particle-size distributions, were conducted during June 2007 with additional surveys conducted through May 2008. At the Sand Creek site, there was insufficient water present in the channel when the channel was surveyed to define water-surface elevations. In order to get water-surface elevations for calibration, two pressure transducers were installed to measure stage during periods of flow. Streamflow measurements and total suspended-sediment samples were collected between August 2007 and October 2008. A subset of the suspended-sediment samples was analyzed for sand concentrations and silt-andclay concentrations, and a smaller subset was analyzed for the full particle-size distribution of the sand and silt-and-clay fraction.

\section{Measurement of Stream Stage, Velocity, and Discharge}

Routine discharge measurements were made at the Monument Creek and Sand Creek sites. Discharge measurements were made using standard USGS methods to define stage-discharge relation curves, hereafter referred to as "rating curves," at the Monument Creek and Sand Creek sites (Carter and Davidian, 1968; Buchanan and Somers, 1969). Two pressure transducers were installed at each site to supplement the stage data collected at the stream gages. Instantaneous stage, velocity, and streamflow data were obtained from discharge measurements of Monument Creek and Sand Creek.

\section{Measurements of Channel Topography}

Reaches were surveyed with a Trimble Model R8 Global Navigation Satellite System survey-grade global positioning system (GPS) operated in real-time kinematic (RTK) mode. The RTK GPS equipment uses a radio to transmit data from a stationary GPS receiver (base) to one or more mobile GPS receivers (rovers) where topographic measurements are collected and computed in real time (Trimble Navigation Limited, 1998). During each topographic survey, the base receiver was positioned over a permanent benchmark located in close proximity to the reach surveyed (figs. 3 and 4). Benchmarks were placed by USGS personnel, and the horizontal and vertical coordinates were determined by a static GPS survey. The data were post-processed by the National Geodetic Survey's 


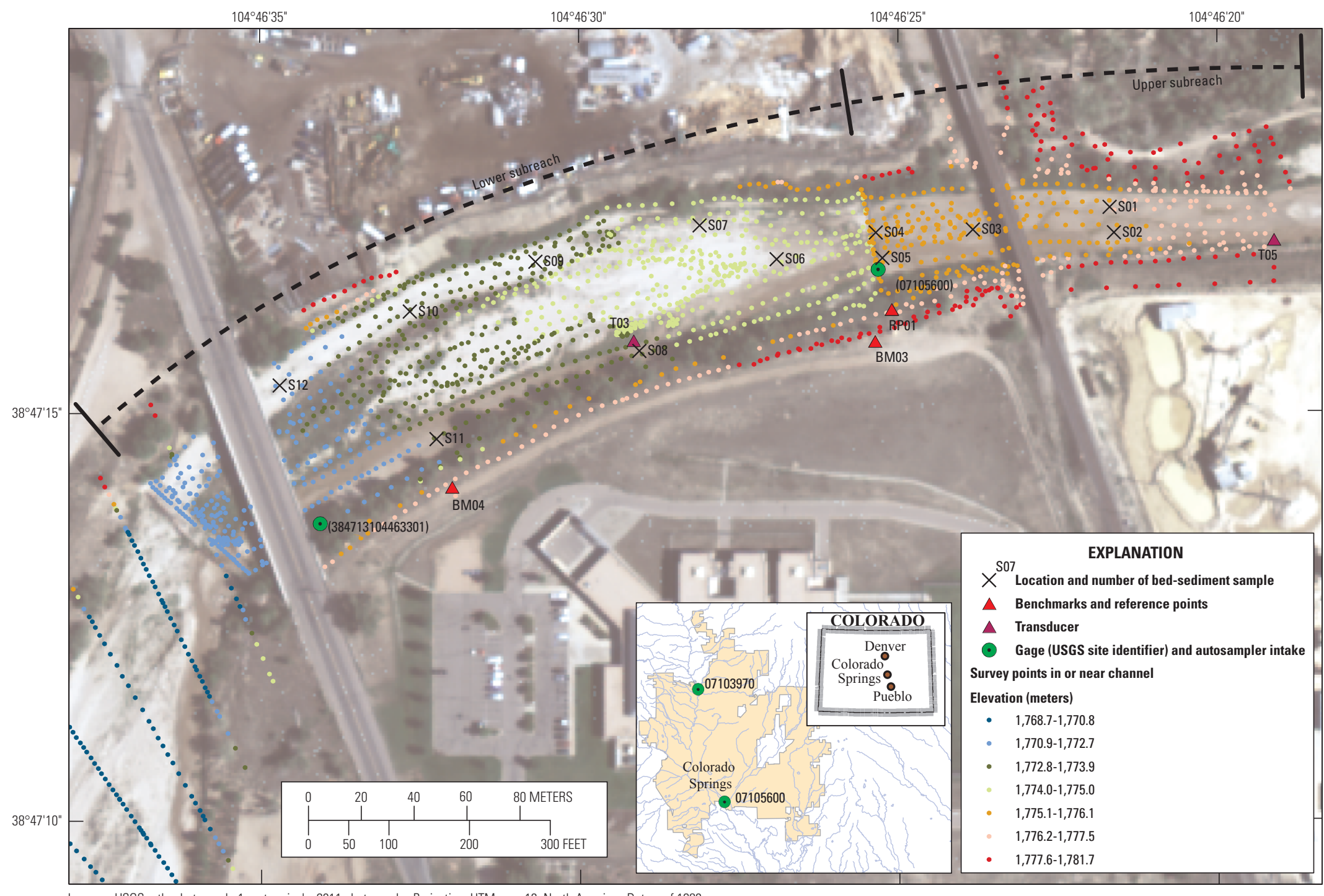

Figure 4. Location of the Sand Creek study site in the vicinity of Sand Creek near Las Vegas Street (U.S. Geological Survey (USGS) site 07105600) with location of benchmarks, reference points, transducers, auto-sampler intakes, and survey points. 
On-line User Positioning Service (http://www.ngs.noaa. gov/OPUS/). Topographic measurements collected with the survey-grade GPS in RTK mode have a horizontal accuracy of \pm 1 centimeter $(\mathrm{cm})$ and a vertical accuracy of $\pm 2 \mathrm{~cm}$ (Trimble Navigation Limited, 2009). Topographic data collected with the GPS were primarily along transects oriented parallel to the principal flow direction in the reaches; additional topographic data were collected as shown in figures 3 and 4, which show the planform locations of the raw survey points color-coded for elevation at the two sites. The positions surveyed with the roving receivers were stored in the data collectors and later downloaded and integrated to make elevation grids of the two study sites.

Topographic measurements at each site were made over a reach length of approximately 10-20 stream widths (figs. 3 and 4). This minimized the potential for errors in model predictions near the gage and the autosamplers that were due to unquantified lateral distributions of flow at the upstream end of the reach. The Monument Creek and Sand Creek models were separated into two reaches because of the presence of the GCS.

\section{Measurement of Suspended-Sediment Concentration and Particle Size}

In response to the signal from the DCP, the ISCO autosamplers used a peristaltic pump to purge the sample tubing prior to and after sample collection by pumping air through the tubing out to the stream. To collect a sample of water, the pump reversed direction creating a vacuum in the sample tubing. The resulting suction drew water from the stream, and twenty-four 500-milliliter $(\mathrm{mL})$ bottles were sequentially filled to a calibrated volume. These samplers provided relatively infrequent (daily) samples during low flow and more frequent samples (typically hourly) based on stage and rate-of-change in stage during storm runoff events.

The downstream samplers provided critical verification information for the model results and calibration information for some of the suspended-sediment methods. Both the verification and calibration information are described in the section "Suspended-Sediment Modeling." In addition, suspendedsediment data were used to separate wash load and suspended load fluxes for the different particle sizes, which is required for constraining model calculations of suspended-sediment load. Wash load is a special case of suspended load and consists of the smallest particles, silt and clay, which usually are absent on the streambed (Ritter and others, 2002). Like the dissolved load of a chemical constituent, these small particles are distributed uniformly throughout the flow, so their sedimenttransport rate can be determined from a single sample at any location within a gaged cross section. Once the wash load was separated from the total suspended-sediment load, the remaining information on coarser material concentration and size distribution was used to determine the size distribution of sand on the riverbed. Sediment-size information from these samples was determined through analysis of sand and silt-and-clay concentrations, hereafter referred to as "sand-fine samples." A more detailed nine-point particle-size, hereafter referred to as "9-point samples," analysis was carried out for a subset of all the samples collected. All samples were analyzed at the USGS Iowa Water Science Center Sediment Laboratory using standard methods (Guy, 1969).

Programmable DCPs were co-located with autosamplers at monitoring locations. DCPs were programmed to measure and record stage at 5- or 15-minute intervals and record autosampler activation. During storms, DCPs evaluated stage and rate-of-change in stage and signaled autosamplers to collect a sample based on programmed minimum stage and rate-of-change in stage thresholds. Autosamplers logged the dates and times of sample collections. During rapid changes in stage, DCPs signaled automatic samplers to collect samples at 5 -minute intervals. As the rate-of-change in stage decreased, frequency of sample collection by the automatic samplers decreased to 30- and 60-minute intervals. When stage dropped below stage thresholds, DCPs no longer signaled automatic samplers to collect a sample. Different laboratory methods were employed to evaluate sediment concentration in the water samples collected because the size of suspended sediment is not static and can increase and decrease with change in streamflow (Leopold and others, 1964; Knighton, 1998; Ritter and others, 2002). Based on stage during time of collection, sediment samples were analyzed for suspended-sediment concentration, sand-fine concentration, or 9-point analysis (table 1). Nine-point analyses were limited to samples collected at or near the peak streamflow for each sampled event when stream energy is greatest and may transport larger size sediments. Nine-point analyses provided detailed data on size of sediments in suspension during peak streamflow. Analyses for sand-fine concentrations were generally associated with samples collected immediately preceding and (or) following the peak streamflow. The sand-fine analyses provided concentration data for sand-sized particles and silt-and-clay sized particles. The remaining samples (collected after peak streamflow) were analyzed for suspended-sediment concentration, and no distinction was made between sand and silt-and-clay sized particles (table 1).

\section{Measurement of Bed-Material Particle Size}

Bed-material samples were collected using a US BMH53 sampler (Edwards and Glysson, 1999) at 19 locations at the Monument Creek site (fig. 3) and 12 locations at the Sand Creek site (fig. 4) to characterize the size distribution and the spatial variation of particle sizes on the bed. Sample sites were selected randomly. This information was used in the flow model to estimate channel roughness and in the suspendedsediment computations. Particle-size analysis (Guy, 1969) was used to determine the detailed distribution of sand sizes. 
Table 1. Suspended-sediment analyses and size fraction data provided by each analysis.

\begin{tabular}{|c|c|c|c|c|c|c|c|c|c|c|c|c|}
\hline \multirow{2}{*}{ Analysis } & \multirow{2}{*}{$\begin{array}{l}\text { Total concen- } \\
\text { tration }\end{array}$} & \multirow{2}{*}{$\begin{array}{l}\text { Sand, } \\
\text { percent greater } \\
\text { than } 0.0625 \mathrm{~mm}\end{array}$} & \multirow{2}{*}{$\begin{array}{l}\text { Silt and clay, } \\
\text { percent finer } \\
\text { than } 0.0625 \mathrm{~mm}\end{array}$} & \multicolumn{9}{|c|}{ Particle size, in millimeters, percent finer than } \\
\hline & & & & 0.5 & 0.25 & 0.125 & 0.0625 & 0.031 & 0.016 & 0.008 & 0.004 & 0.002 \\
\hline $\begin{array}{l}\text { Suspended- } \\
\text { sediment } \\
\text { concentration }\end{array}$ & $\mathrm{X}$ & -- & -- & -- & -- & -- & -- & -- & -- & -- & -- & -- \\
\hline $\begin{array}{l}\text { Sand-fine } \\
\text { concentration }\end{array}$ & $\mathrm{X}$ & $\mathrm{C}$ & $\mathrm{X}$ & -- & -- & -- & -- & -- & -- & -- & -- & -- \\
\hline Nine-point & $\mathrm{X}$ & $\mathrm{C}$ & $\mathrm{X}$ & $\mathrm{X}$ & $\mathrm{X}$ & $\mathrm{X}$ & $\mathrm{X}$ & $\mathrm{X}$ & $\mathrm{X}$ & $\mathrm{X}$ & $\mathrm{X}$ & $\mathrm{X}$ \\
\hline
\end{tabular}

\section{Computational Methods for Flow and Suspended Sediment}

This section presents a brief description of the flowmodeling application and a brief description of the suspendedsediment modeling both in terms of application and verification. The foundation of the detailed suspended-sediment transport modeling in this report is to provide an accurate prediction of the flow field at the study sites. To accomplish this, the USGS Multi-Dimensional Surface-Water Modeling System (MD_SWMS) was used with measured hydrographs and the topographic data described in the section "Measurement of Channel Topography." The modeling system, MD_SWMS, is a USGS developed public-domain pre- and post-processing application for computational models of surface-water hydraulics and sediment transport. In addition to computational models, the system includes a graphical user interface (McDonald and others, 2001) that allows the modeler to build and edit data sets of the modeling system's computational surface-water models. For the modeling at the two sites in the Fountain Creek watershed, three-dimensional surface-water modeling was accomplished using Flow and Sediment Transport with Morphologic Evolution of Channels (FaSTMECH); this model is one of the computational models within MD SWMS and was developed by the USGS (Nelson and McDonald, 1997; Nelson and others, 2003). FaSTMECH includes a 2-dimensional, vertically averaged model and a submodel that calculates vertical distribution of the primary velocity and the secondary flow about the vertically averaged flow. This method, commonly referred to as quasi-3-dimensional, has been shown to simulate the velocity field, bed shear stress, and resulting patterns of erosion and deposition where secondary flows are significant, such as meander bends, without the complexity of a 3-dimensional model. This model has been used and verified extensively on a wide variety of rivers (Conaway and Moran, 2004; Kinzel and others, 2009; Logan and others, 2011; McDonald and others, 2006; McDonald and others, 2010).

Simulations of flow for Monument Creek and Sand Creek were developed using the surveyed topographic and roughness information from each reach. For each discharge of interest (high-streamflow events with pumped suspended-sediment samples), stage for that discharge is used as a boundary condition, and the bed roughness was set by a combination of the measured particle sizes on the bed and calibration. FaSTMECH model simulations of predicted stage were compared to measured stage. Differences between the predicted stage value and the measured stage value for various channel roughness values were evaluated by computing the root mean squared error (RMSE) (Helsel and Hirsch, 1992). The flowmodel results provide the information, including boundary shear stress, needed for computation of suspended-sediment transport during various streamflow events at each site.

\section{Suspended-Sediment Modeling}

With the measured particle sizes of bed material and both velocities and boundary shear stresses from the flow modeling, there is enough information available to compute suspendedsediment concentrations and loads over a hydrograph or for specific steady flow conditions. Three different methods of suspended-sediment concentration estimates were evaluated in this study. In each case, the particle sizes were used to determine settling velocities based on relations given by Dietrich (1982). A comparison of the different methods and a relative cost effectiveness and evaluation of accuracy was done in the context of a broader watershed-wide application of these techniques. Model predictions for suspended sediment at the location of the autosampler nozzle for the first two methods discussed below were calibrated for the best-fit value of gamma, the resuspension parameter, which is a dimensionless parameter in the reference concentration equations relating bed shear stress to near-bed suspended-sediment concentration for each size class present in the bed (Smith and McLean, 1977). The details of the three methods are described in the following sections.

\section{Rouse Method with Smith/McLean Reference Concentration}

The first method for computing suspended-sediment concentrations and fluxes by size class is based on the method described by Rouse, and empirically calibrated by Smith and 
McLean (1977) and McLean (1992). This method predicts the vertical profile of suspended-sediment concentration as a function of the local (at a point) bed shear stress, the critical shear stress for motion of the particles, the settling velocities of particles in suspension, and a single empirical coefficient relating the concentration of particle sizes in the bed with the concentration in suspension. An assumption in this method is that the flow transporting the sediment is steady and horizontally uniform, where horizontally uniform means that there are no spatial accelerations in the flow. The strength of this method is that it is easy to apply particle size; the weakness of the method is that real river flows are not steady and uniform. In some locations, suspended-sediment concentrations are poorly correlated with the local bed shear stress; this is especially true in regions with strong lateral shear. In some cases, this issue is avoided by dealing with a spatially averaged view of the suspended sediment, but there is no guarantee that a spatially averaged view is at all appropriate. In most nonlinear problems, the solution for average conditions is a poor approximation to the average of the solution for real conditions. Furthermore, various studies suggest that the empirical coefficient used for the reference concentration varies widely (Harris and Wiberg, 2001); even the functional form of the reference concentration equation is not universally accepted (Garcia and Parker, 1991). Nevertheless, this is the simplest method requiring the fewest field data. This method yields concentration throughout the flow. Subsequently determining the fluxes (loads) requires multiplying the concentration at each point by the computed downstream component of velocity and stage and averaging over each cross section.

\section{Rouse Method with Reference Concentration Equation Calibrated with Field Data}

This method is essentially the same as the first method described above, with the important exception that the reference concentration for the Rouse solution is set using field data. Thus, errors associated with the form of the reference concentration equation and its empirical parameters are avoided. However, the method still avoids dealing with real spatial nonuniformity caused by local spatial accelerations and decelerations. The results from this method should be more accurate because they are more closely tied to the observations. Seeing as how this method requires more data, it is important to weigh the improved accuracy in lieu of the additional costs of a more detailed data collection strategy. In most cases the increased accuracy may not be substantial. This method requires more than one autosampler at each of the two sites. At one location, the autosampler collects the calibration data set. At the second location, the autosampler collects the verification data set. To ensure the verification data set is independent of the calibration data set, the two samplers should be located as far apart as feasible at each of the sites.

\section{Advection-Diffusion Solution}

The third method for computing suspended-sediment concentration and flux involved using the computational solution of the equation expressing mass conservation for the suspended sediment (Fischer and others, 1979). This equation explicitly includes horizontal variation in streamflow and is called the advection-diffusion equation for suspended sediment. Using this method, the local concentration is not dependent only on the local bed shear stress, but also depends on the spatial advection of suspended material in the stream (even areas with low bed shear stresses can have high concentrations if the flux of sediment from upstream is large and the settling velocity of the material is relatively small). The strength of this method is that it addresses spatial nonuniformity in the flow. The weakness is that it requires a much more complicated numerical model and requires boundary conditions in the form of either a measurement or computation of the suspended-sediment concentration at the upstream end of the reach and a so-called "reference flux" condition at the bed. For these boundary conditions, the model will use both of the Rouse methods. In many, but not all cases, the solution becomes somewhat independent of the upstream boundary condition if the reach is of sufficient length; hence, the desire to space autosamplers as far apart in each reach as is practical. As part of the numerical solution process, this method yields both concentration and sediment flux for each particle size throughout the computational domain. The average of these concentrations can be used to predict total suspended load.

\section{Statistical Analysis}

Simple linear regression was used to determine the best straight-line fit between two variables (one dependent and one independent variable) and obtain a predictive equation. The coefficient of determination, $r$-squared $\left(\mathrm{r}^{2}\right)$, is a statistical measure of how well the predictive equation (regression line) fits the real data points. It varies between 0 and 1 and indicates the amount of variability in the dependent variable described by the independent variable (that is, an $r^{2}$ value of 0 indicates that there is no relation between the dependent and independent variables; and an $r^{2}$ value of 1 indicates that there is a perfect relation between the dependent and independent variables) (Helsel and Hirsch, 1992).

\section{Flow and Suspended-Sediment Model Development}

The following sections discuss the results of the field data collections for channel particle size and suspended-sediment concentration and grain size, and the application of that data to the flow and suspended-sediment model development and calibration. 


\section{Field Data Integration}

The basic field data used for the modeling effort consisted of the survey data shown in figures 3 and 4 , the bed material particle-size data used for roughness and suspended-sediment modeling, and gage information that provided a relation between stage and streamflow (discharge) at a single location. In addition to these basic data required for setting up the model, suspended-sediment-concentration data were collected at the autosampler locations to provide calibration and verification data. Water-surface elevations were measured to verify flow-model results, and about 3 percent of the suspendedsediment samples were analyzed for particle-size distributions in order to compare them to model predictions and to ascertain how large the washload component of suspended-sediment load was at the field sites. Washload refers to the portion of the suspended material that is not present in the bed, or at least is present in such small amounts that the total amount of washload in suspension is determined primarily by upstream supply, not availability in the bed.

\section{Bed Material Particle-Size Data}

Bed-sediment particle sizes at both sites (figs. 5 and 6) were dominated by sand-size ( 0.063 to $2 \mathrm{~mm}$ ) and gravelsize (2 to $64 \mathrm{~mm}$ ) particles. At the Monument Creek site, the median (50-percent finer) bed-sediment particle size varied from about $1 \mathrm{~mm}$ (coarse sand) to $4 \mathrm{~mm}$ (very fine gravel), with the exception of a single sample (sample M06, fig. 5), that was collected at the top of a bar near the upstream end of the reach. Particle size of bed sediments of sample M06 was predominately (74 percent) finer than $0.25 \mathrm{~mm}$ (fine sand) and indicate the presence of an upstream source of fine sediments that were not evident in other bed-sediment samples collected at the Monument Creek site. The apparent presence of an upstream source of fine sediments and the small percentage of fine sediments in other samples collected suggests that particles less than $0.25 \mathrm{~mm}$ are readily transported through the reach under the current hydrologic regime. Figure 7 shows the distribution of bed sediments constructed from the composite of the individual sample results. Generally, the particle-size variation through the reach was small enough that it appeared reasonable to use the single composite bed-sediment distribution to represent the reach. This composite sample for Monument Creek, shown as a solid line in figure 7, had a median size of about $2 \mathrm{~mm}$ and a 16th and 84th percentiles (percent finer) of about 0.6 and $7 \mathrm{~mm}$, respectively. In Sand Creek, the bed sediment was slightly finer in size, with the median particle size varying spatially between about 0.5 and $2 \mathrm{~mm}$ (fig. 6). The presence of a substantial upstream source of fine sediments was not evident in samples collected at the Sand Creek site as sample M06 suggested at the Monument Creek site. This would suggest that such a source does not exist (unlikely given the characteristics of the Colorado Piedmont through which Sand Creek flows) or that, similar to the Monument
Creek site, fine particles are readily transported through the reach. As in the case of Monument Creek, the distribution of the composite sample was assumed to be suitable to represent the bed-sediment distribution of the reach because the differences between individual samples were not large, especially considering the wide variation in size at any single point. The bed-sediment distribution based on the composite of all samples collected at Sand Creek had a median size of about $1.4 \mathrm{~mm}$ with 16th and 84th percentiles of about 0.4 and 3.0 $\mathrm{mm}$, respectively. The general distribution of bed sediments at the Monument and Sand Creek sites were similar (fig. 7), with Sand Creek trending toward a slightly larger percent of particles in the very coarse sand (1 to $2 \mathrm{~mm}$ ) to very fine gravel ( 2 to $4 \mathrm{~mm}$ ) size classes.

\section{Suspended-Sediment Data}

Concentrations of suspended sediment and sand in samples collected from Monument Creek during a series of storms in August 2008 varied temporally in response to changes in streamflow (fig. 8). Suspended-sediment concentrations during storms were largest at or near peak streamflow.

The particle-size distributions of the suspended-sediment samples for two pumped samples at the Monument Creek site (fig. 9) and three pumped samples at the Sand Creek site (fig. 10) were collected from a single point in the vertical by autosamplers. These sizes are dramatically finer than the bed material, reflecting the fact that larger particles cannot generally be put into suspension even at very high streamflows in these systems. At the Monument Creek site, a proportion of the sediment-particle sizes in suspension are present in the bed, so this system is not completely dominated by washload. Therefore, a model based on measured bed material should have some predictive value. This relation is less evident at the Sand Creek site where suspended-sediment size distributions were much finer than essentially all of the bed material. This may be associated with the fact that the peak streamflows at which suspended-sediment size distributions were measured at the Sand Creek site was greater than the peak streamflows at which suspended-sediment size distributions were measured at the Monument Creek site. However, there may be also an issue with these measurements related to the length of the tubing used on the autosampler (Bent and others, 2001) and the sampling efficiency as a function of flow velocity and orientation of the autosampler intake nozzles (Winterstein, 1986). Some researchers have suggested that long tubing runs and intake orientation inhibit the collection of sand-size material. As addressed in more detail in the section "Flow Model Calibration," other issues at the Sand Creek site rendered this question of little importance, at least for this initial study.

In Monument Creek, the suspended-sediment concentration increased with streamflow (fig. 11). Equation 1 describes this log-log relation between streamflow $(x)$ and suspendedsediment concentration $(y)$. This relation is less evident in Sand Creek (fig. 12), which appeared to show some increase in suspended-sediment concentration with streamflow (eq. 2), but 


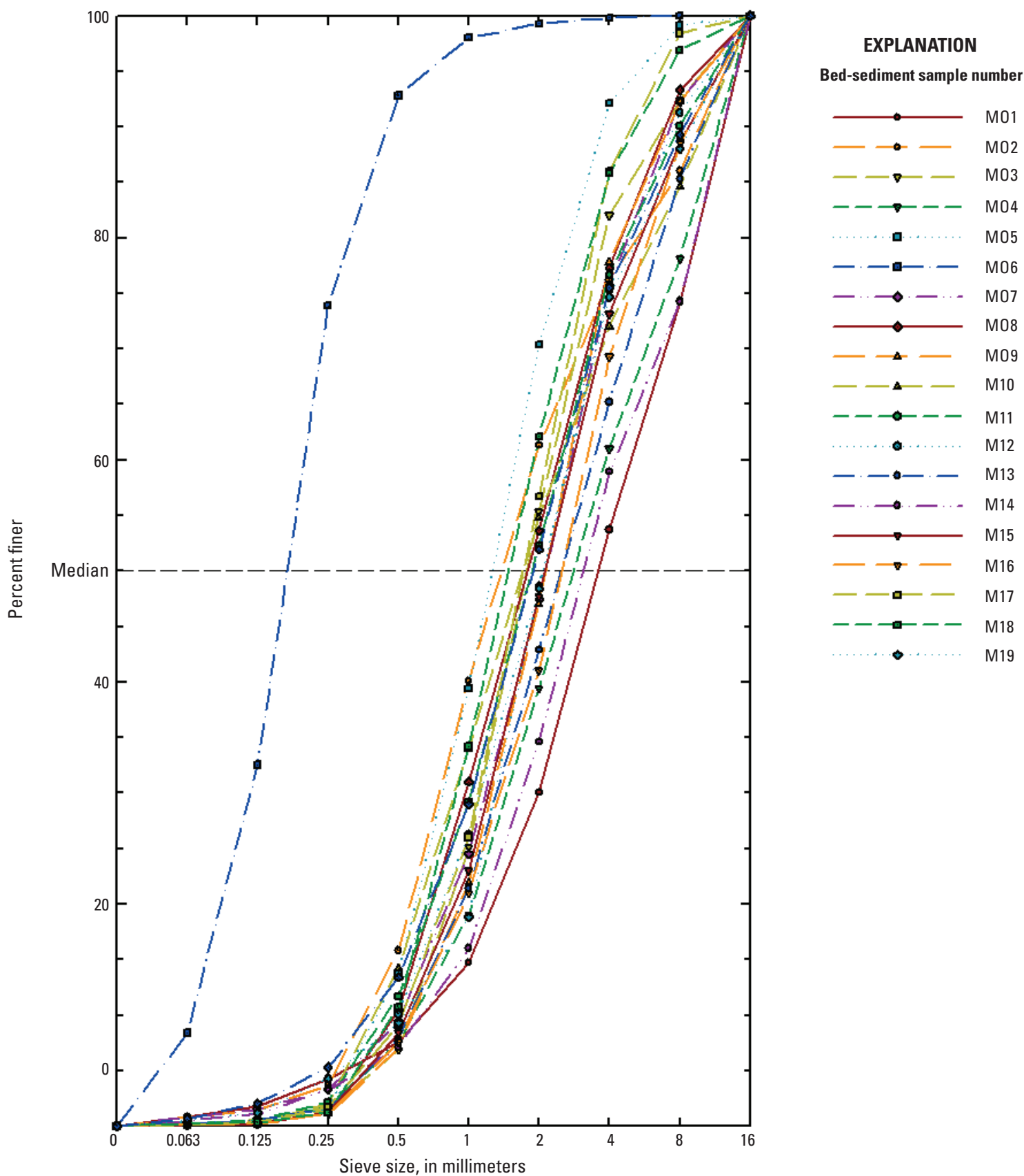

Figure 5. Particle-size distribution data for bed-sediment samples collected in Monument Creek near U.S. Geological Survey gage site 07103970 . (Sampling locations are shown in figure 3.) 


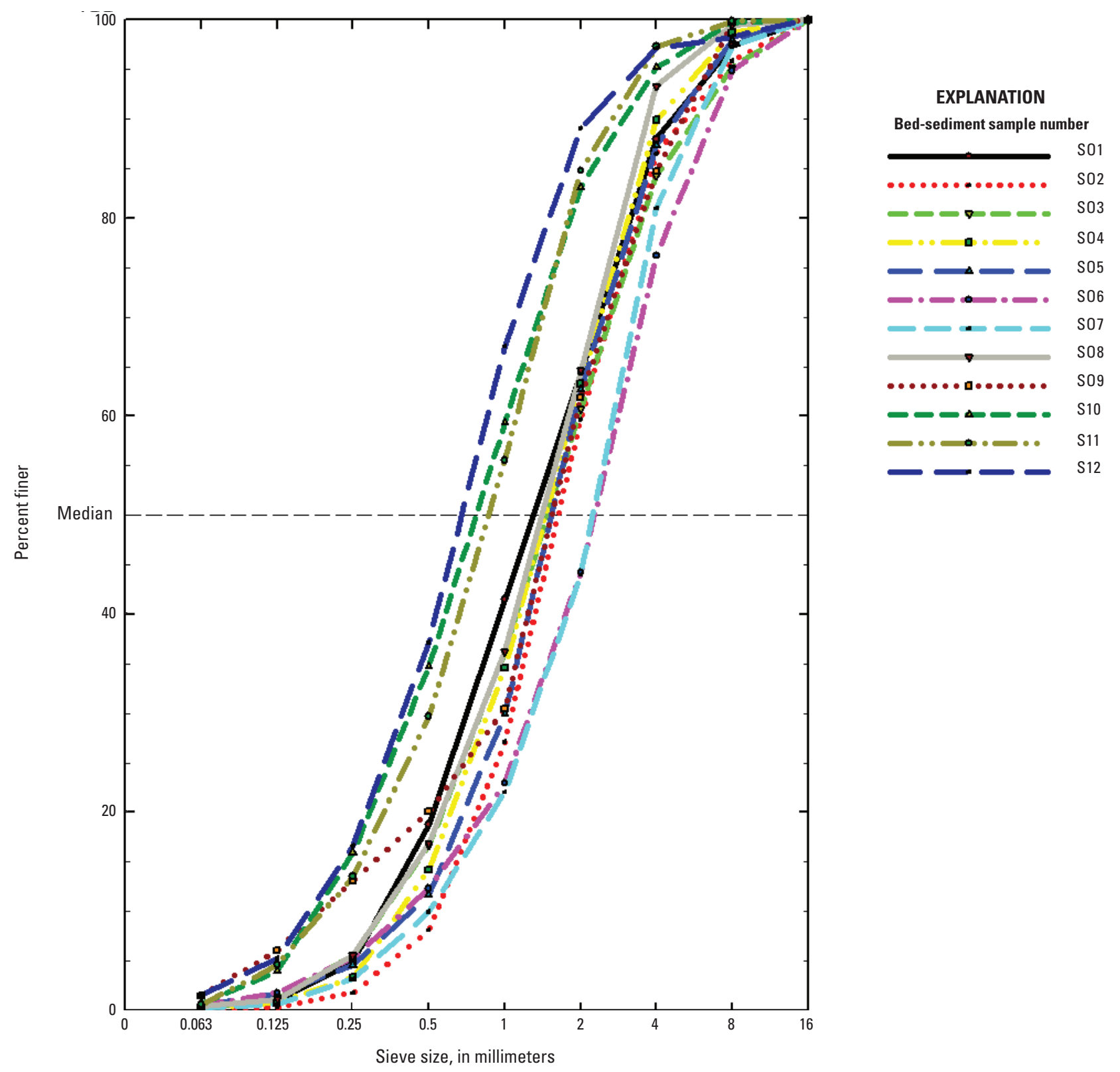

Figure 6. Particle-size distribution data for bed-sediment samples collected in Sand Creek near U.S. Geological Survey gage site 07105600. (Sampling locations are shown in figure 4.) 


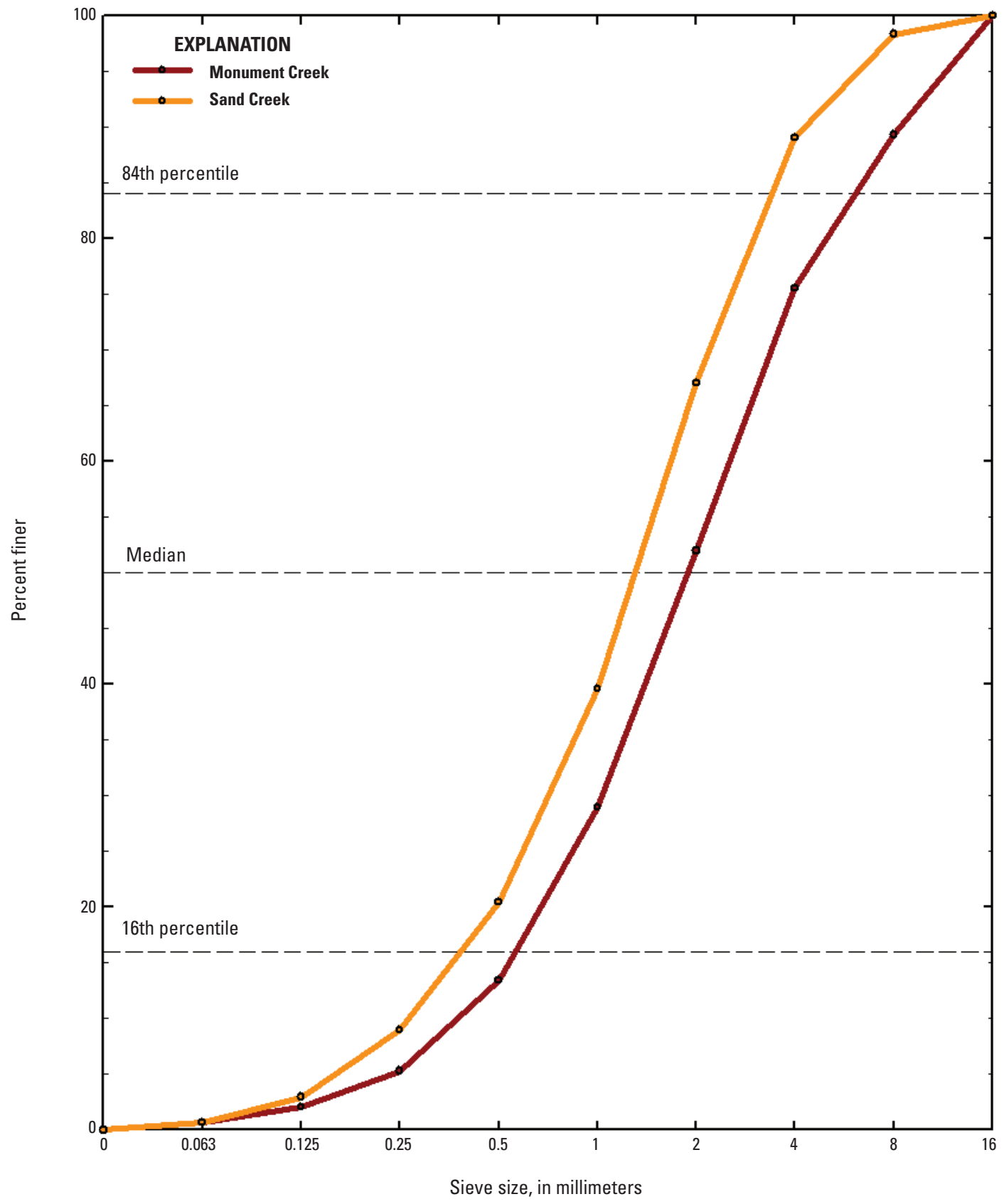

Figure 7. Particle-size distribution for bed sediments for composite of all samples collected in Monument Creek near U.S. Geological Survey gage site 07103970 and Sand Creek near U.S. Geologcial Survey gage site 07105600 . 


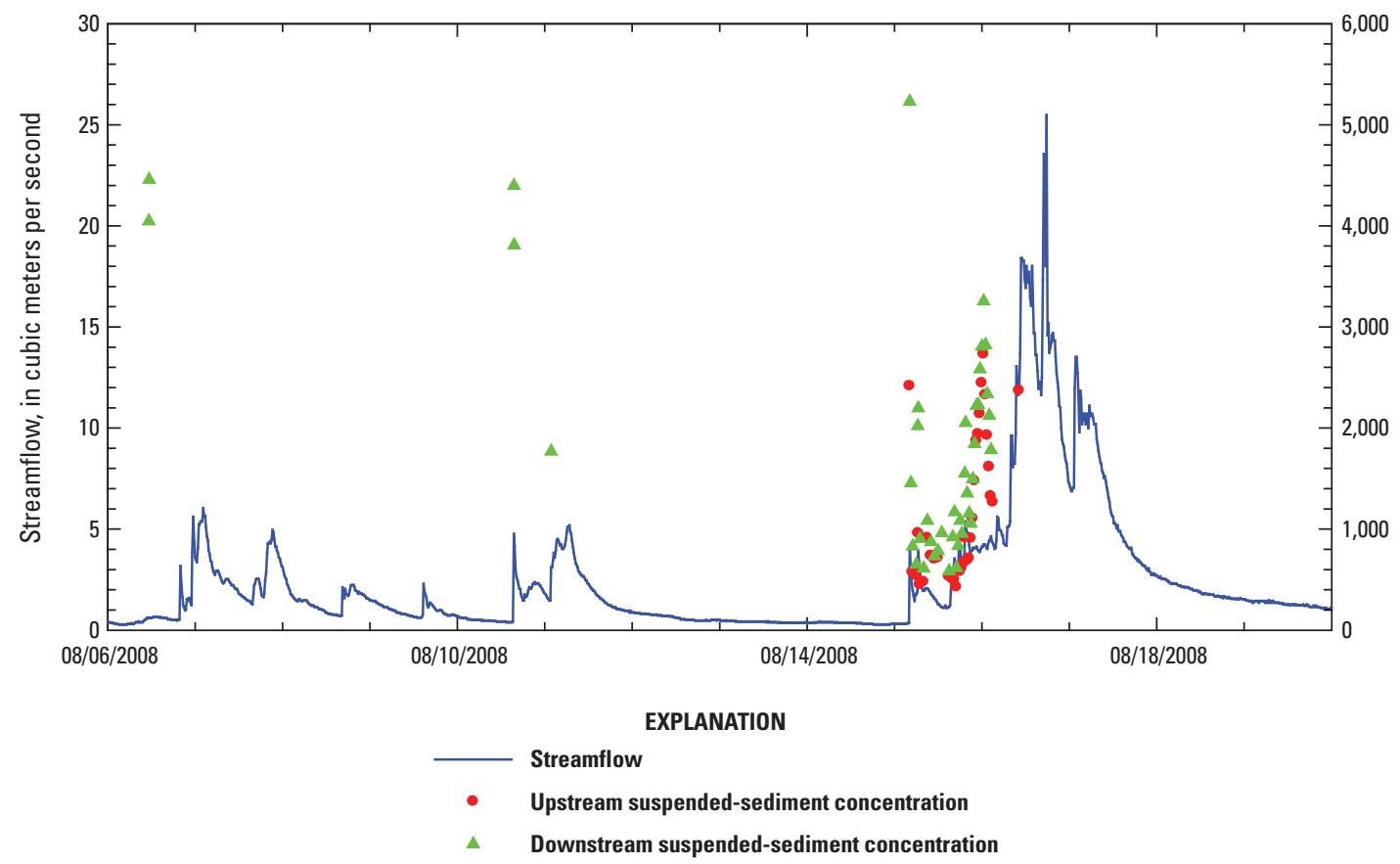

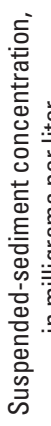

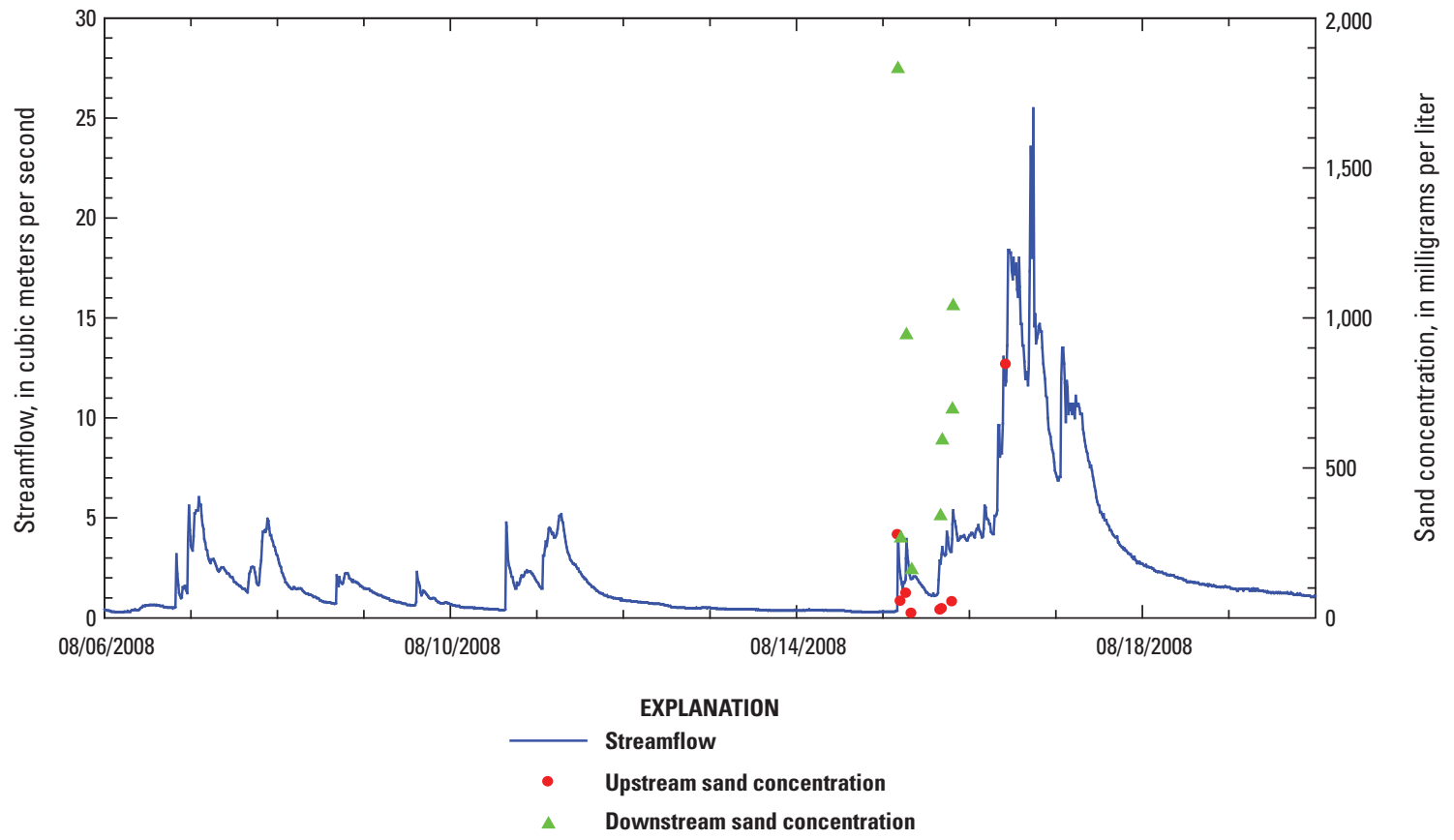

Figure 8. Streamflow, suspended-sediment, and sand concentrations in samples collected from the Monument Creek site during August 2008. 


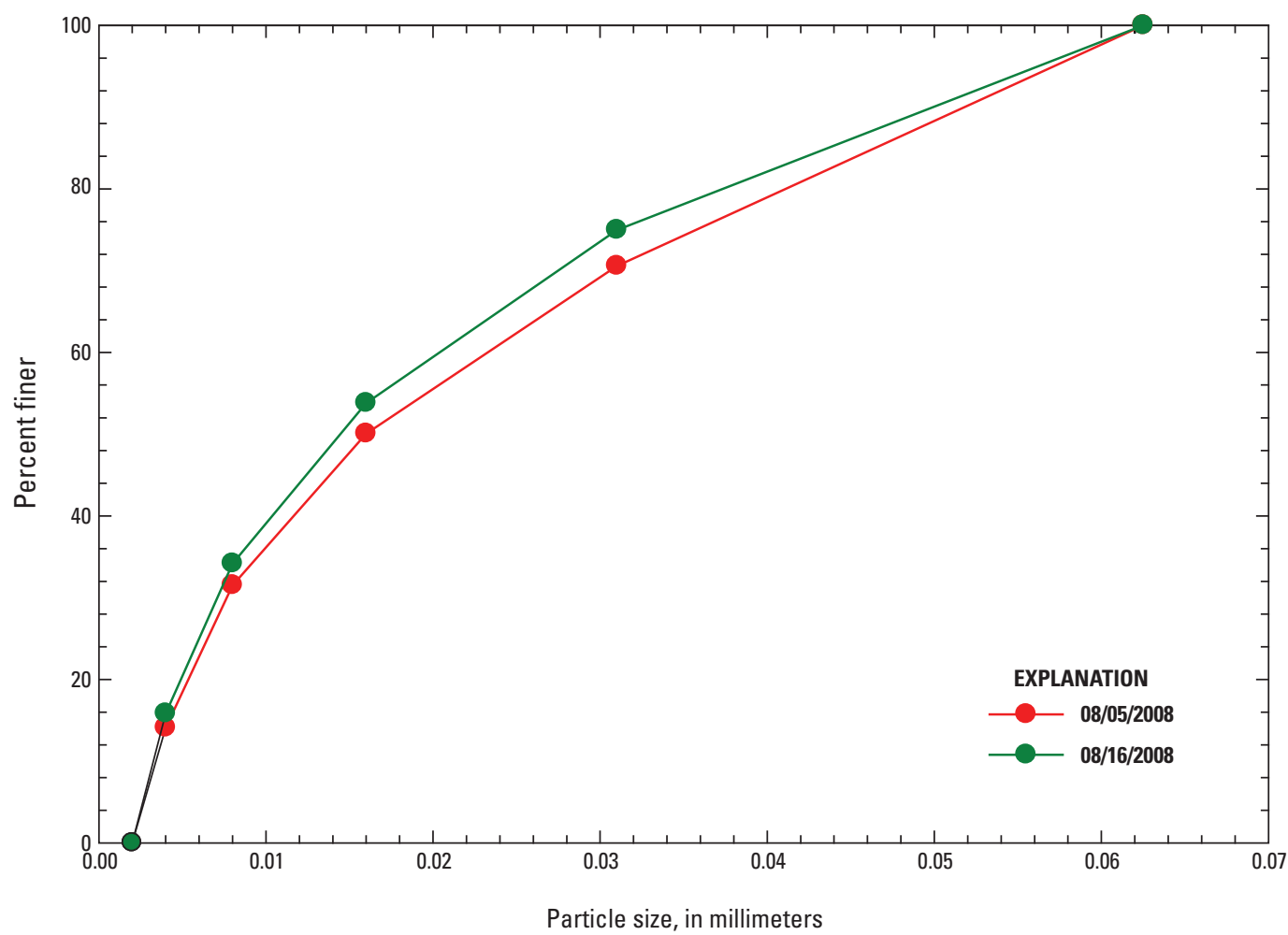

Figure 9. Particle-size distribution data for suspended-sediment samples collected at a single point in the vertical in Monument Creek near U.S. Geological Survey gage site 07103970 (location is shown in figure 3.)

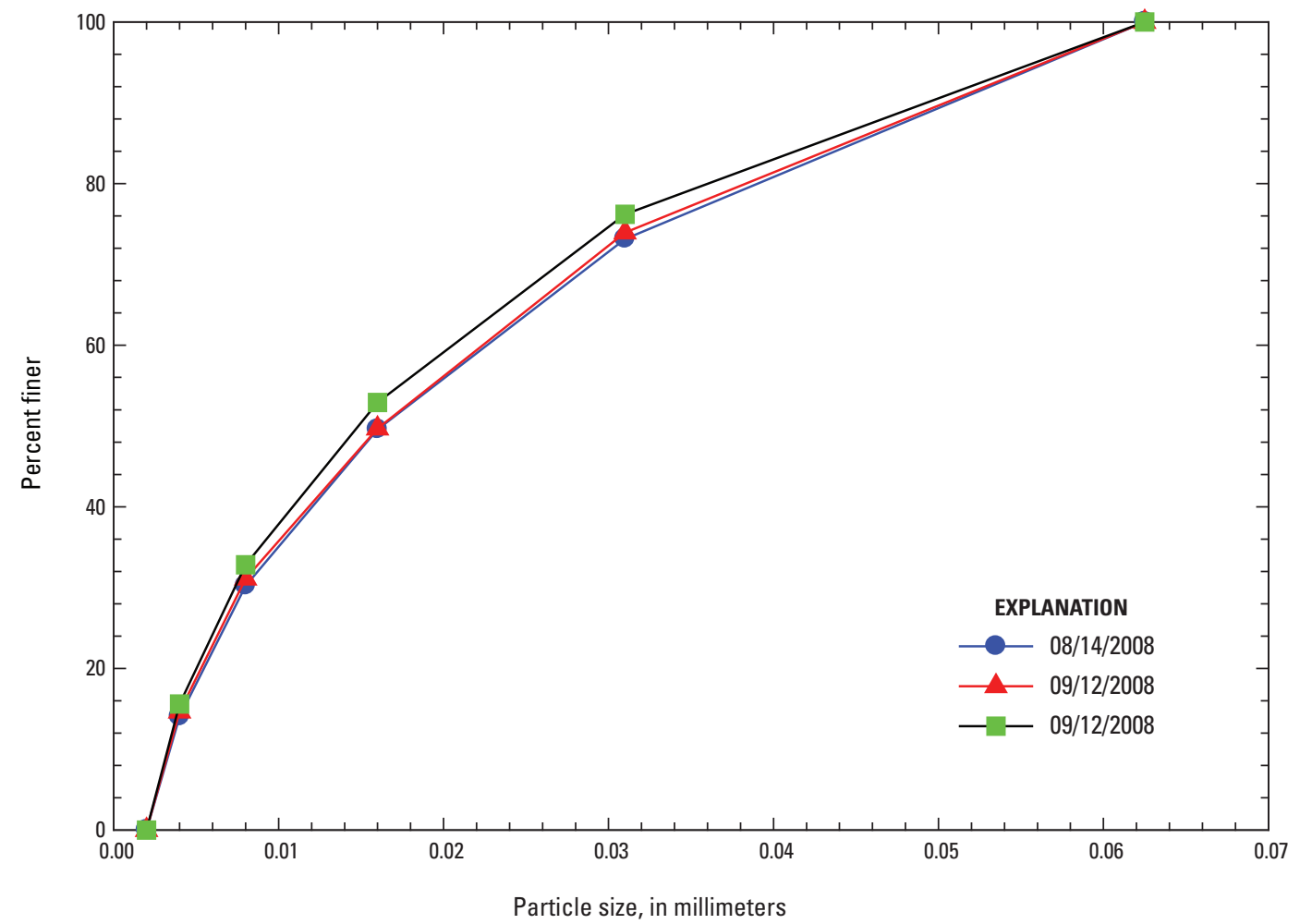

Figure 10. Particle-size distribution data for suspended-sediment samples collected at a single point in the vertical in Sand Creek near U.S. Geological Survey gage site 07105600 (location is shown in figure 4.) 


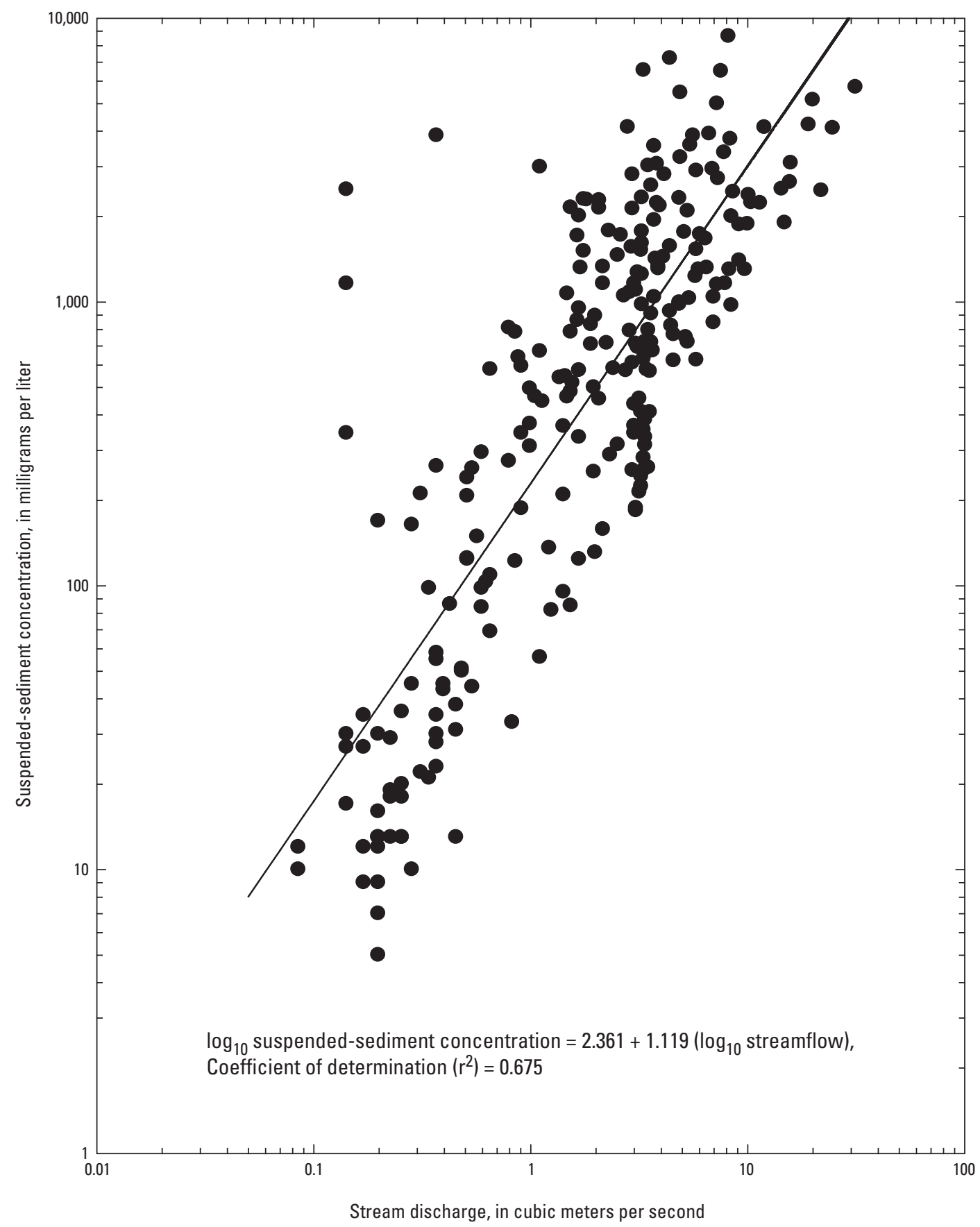

Figure 11. Measured suspended-sediment concentrations of samples collected at a single vertical location in Monument Creek near U.S. Geological Survey gage site 07103970 as a function of streamflow. 


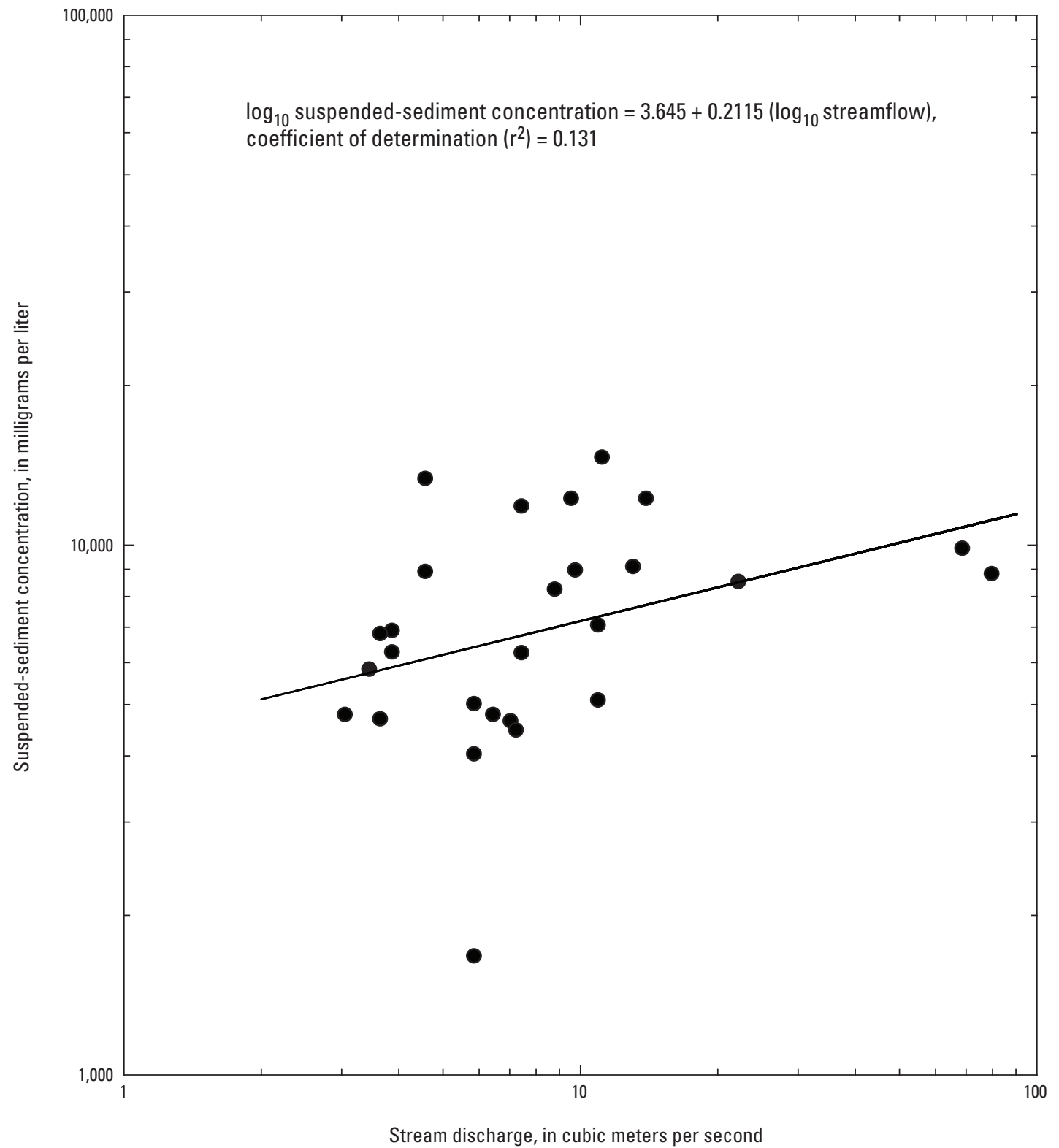

Figure 12. Measured suspended-sediment concentrations of samples collected at a single vertical location in Sand Creek near U.S. Geological Survey gage site 07105600 as a function of streamflow. 
also showed similar concentrations across the range of measured streamflows. Agreement with the measured suspendedsediment particle-size distributions suggested that washload may be dominant at Sand Creek, at least for the streamflows measured. If this is the case for the range of streamflows at Sand Creek, it is doubtful that the proposed method will be successful for that situation. However, at higher streamflows, the proposed method may be appropriate where more of the actual bed material can be put into suspension by the streamflow.

$$
\begin{aligned}
& \log _{10} y=2.361+1.119\left(\log _{10} x\right), r^{2}=0.675 \\
& \log _{10} y=3.645+0.2115\left(\log _{10} x\right), r^{2}=0.131
\end{aligned}
$$

\section{Flow Modeling}

Flow-model development and results are described in this section. For each streamflow of interest (high-flow events with pumped suspended-sediment samples), stage for that streamflow is used as a boundary condition, and the bed roughness was set by a combination of the measured particle sizes on the bed and calibration.

\section{Flow-Model Calibration}

Typically, in cases where channel roughness is dominated by grain roughness rather than bedforms or other bed features, roughness is set in terms of the roughness length, $\mathrm{z}_{0}$ (Middleton and Southard, 1984). This parameter is directly related to particle size using empirical results. For very well sorted, level beds, the value is typically set as 0.033 times the median particle size (Nikuradse, 1933). For more natural, poorly sorted beds with some microscale topography, $\mathrm{z}_{0}$ is usually found empirically to lie in the range of 0.05 to 0.5 times the median particle size. In some cases, researchers (Whiting and Dietrich, 1991) relate the roughness length to the 84th percentile of the bed particle-size distribution, with multipliers ranging from 0.03 to 0.2 for typical beds.

\section{Monument Creek}

For the case of Monument Creek, predictions for $\mathrm{z}_{0}$ ranged from 0.0001 to $0.001 \mathrm{~m}$ based on median particle size, or 0.0002 to $0.0014 \mathrm{~m}$ based on the 84 th percentile of the bed particle size. In order to set $\mathrm{z}_{0}$ more precisely, the FaSTMECH model was run with a range of roughnesses for the streamflow measured during the ground-surface survey (which included water-surface elevations, primarily at edge-of-water). The predicted water-surface elevations were compared to the measured ones and the RMSE (departure of predicted value from true value) (Helsel and Hirsch, 1992) was computed for each choice of roughness. The result of this process is shown in figures $13 A$ and $13 B$, which shows the RMSE as a function of the choice of roughness length, $\mathrm{z}_{0}$. The minimum error (best prediction) was found for a choice of $z_{0}$ of $0.0003 \mathrm{~m}$ for the upper reach and $0.004 \mathrm{~m}$ for the lower reach. The calibrated value for the upper reach lies well within the literature values. The higher roughness length of the lower reach is a result of coarse riffle area composed of large cobbles and small boulders, not sampled as part of the mobile bed, near the downstream end of the reach. Model predictions for water-surface elevation compared to those measured are shown in figures $14 \mathrm{~A}$ and $14 \mathrm{~B}$.

\section{Sand Creek}

There was no value of roughness that gave an acceptable fit at the Sand Creek site. As previously mentioned in the section "Methods of Investigation," there was insufficient water present in the channel at the Sand Creek site when the channel was surveyed to define water-surface elevations. In order to get water-surface elevations for calibration, two pressure transducers were installed to measure stage during periods of stormflow. However, the morphological characteristics of the bed were altered during the first substantial stormflow event during the first year of the study; a maximum discharge of $39 \mathrm{~m} / \mathrm{s}$ occurred on August 16, 2008. Additionally, the downstream transducer was lost during a substantial streamflow event (maximum discharge of $101 \mathrm{~m}^{3} / \mathrm{s}$ ), which occurred on September 12, 2008. Streamflows during the September 11-12, 2008, storm further modified the morphological characteristics of the bed. During these two flow events, large areas of the bed scoured by more than $0.3 \mathrm{~m}$, whereas in other areas of the channel, deposition raised the bed by more than $0.3 \mathrm{~m}$. Transducers were reinstalled for the second year, and some stage data were collected. However, when the calibration process was attempted, no reasonable choice of roughness gave an acceptable fit to the measured water-surface elevations. It appears that this was associated with changes in the bed morphology, so that the original surveyed elevations were not representative of the channel bed when the water-surface elevations were measured. Further analysis at this site was discontinued for this study because of the problem in obtaining representative water-surface elevations, changes in channel geometry, the loss of the downstream transducer, and potential issues with the measured suspendedsediment concentrations due to the length of the intake tube. Future study at the Sand Creek site and (or) sites similar to Sand Creek with the objective of developing streamflow and sediment transport models may require pre- and post-storm channel surveys in order to account for dynamic changes in bed morphology over the study period.

\section{Flow-Model Results}

A complete data set for the analysis presented in this report was collected at the Monument Creek site and is the focus of the remaining report. The Monument Creek site was split into a lower and upper reach, with the division at the 

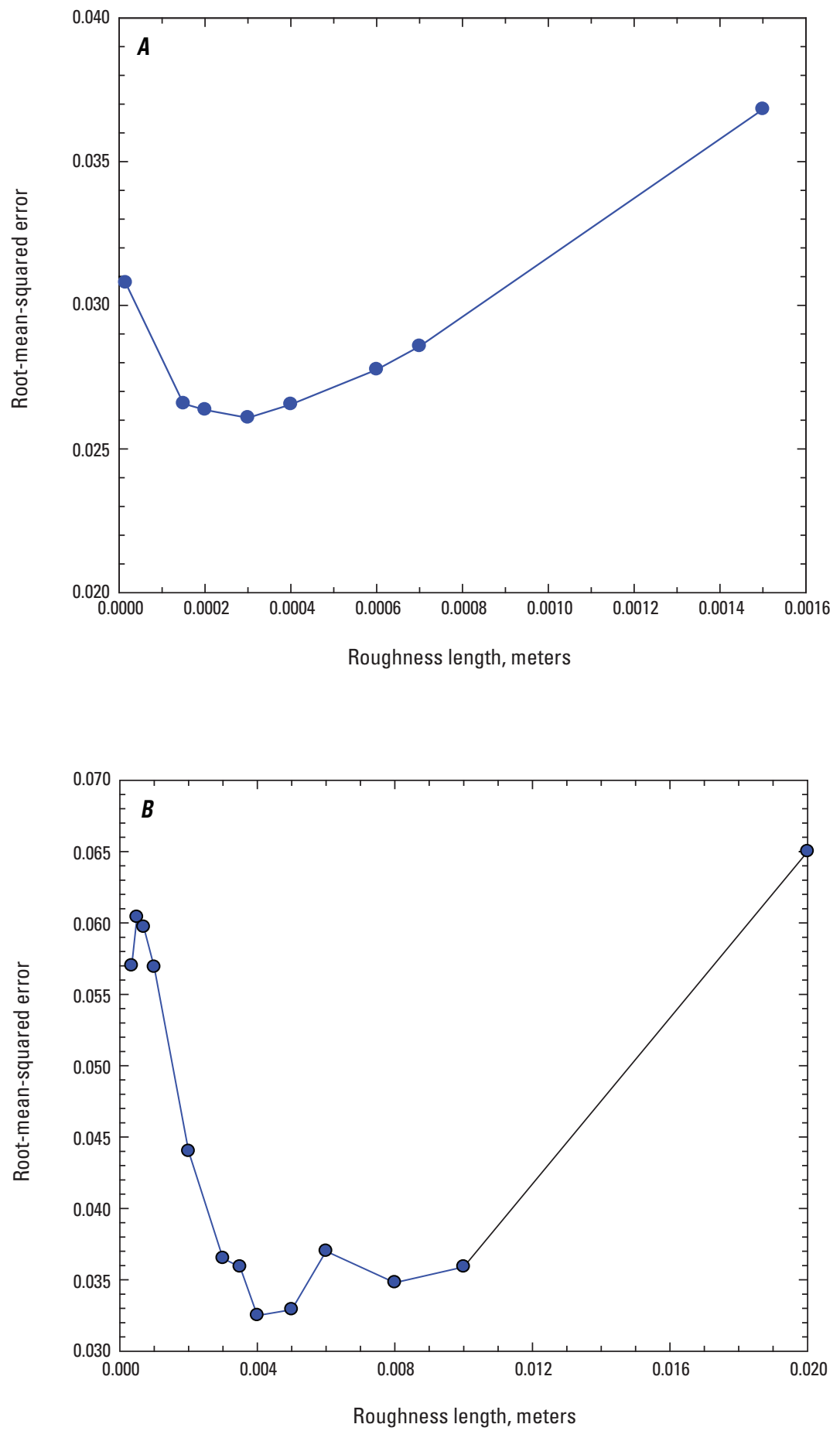

Figure 13. Root-mean-squared error between the measured and predicted water-surface elevation as a function of roughness at $(A)$ the upper Monument Creek reach and $(B)$ the lower Monument Creek reach. 

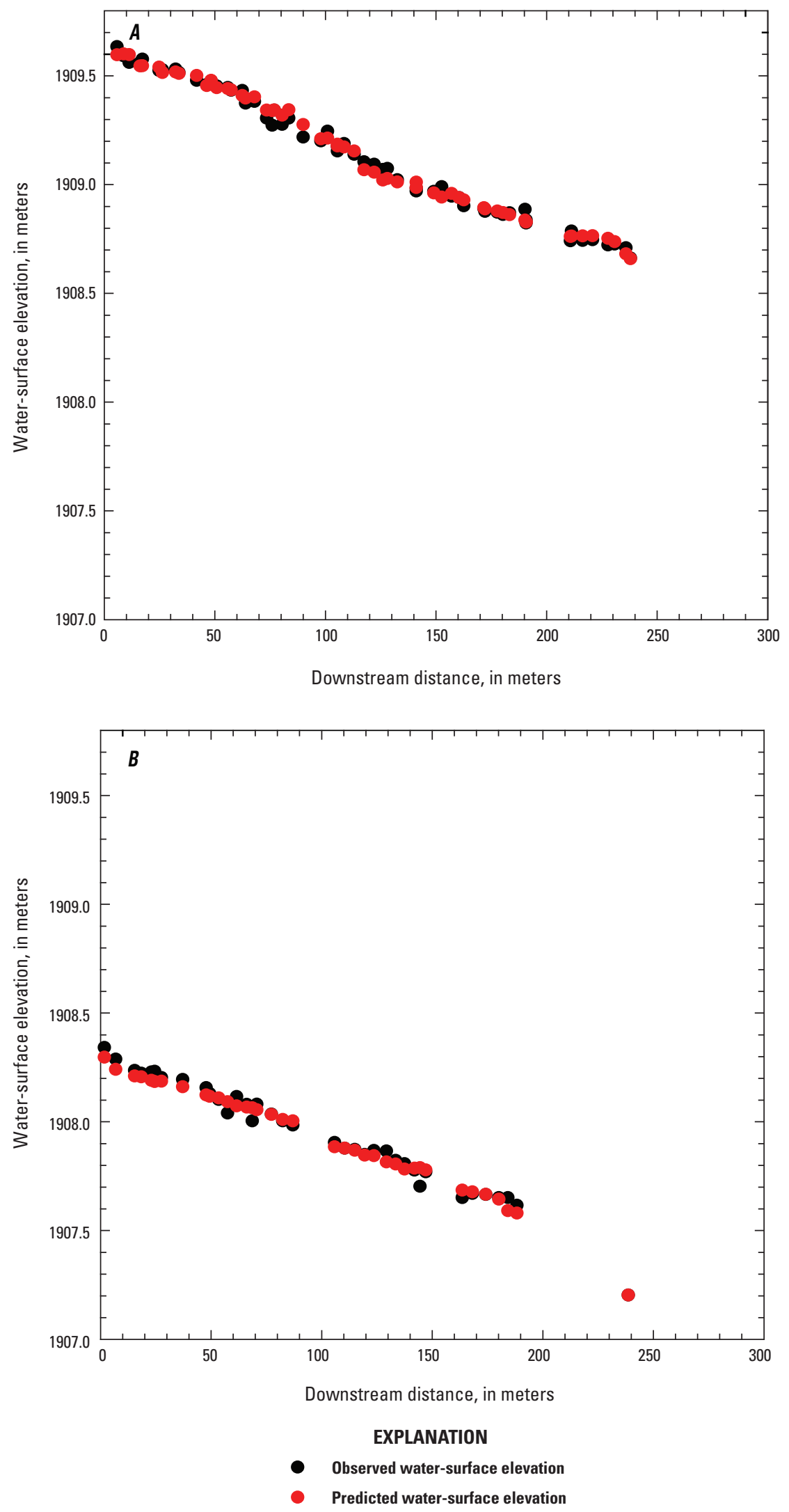

Figure 14. Measured and predicted water surface as a function of streamwise distance in the downstream direction for the calibrated value of roughness at $(A)$ the upper Monument Creek reach and $(B)$ the lower Monument Creek reach. 
GCS present in the channel near the midpoint of the survey (fig. 3). An example of the model predictions for vertically averaged velocity and bed shear stress at the upper Monument Creek site are shown in figures 15 and 16 for the two stormevent discharges during which pumped samples of suspended sediment were collected (August 5 and 16, 2000). These predictions were computed using the measured stage for these events and the calibrated roughness value discussed in section "Flow Model Calibration." Velocity and bed shear stress are the principal outputs of the model used to drive the suspended sediment computations. The bed shear stress is used to compute the reference concentration for the Rouse model, and the predicted velocities (including their vertical structure) are used with the predicted concentration profiles to compute loads in the channel.

\section{Predicted Suspended-Sediment Concentrations}

As previously noted, a substantial amount of the suspended material in samples collected from the upper and lower reach of the Monument Creek site was finer than the particle sizes found in the bed. Thus, a Rouse prediction based only on the bed material sizes and local bed shear stress cannot accurately predict the total suspended-sediment concentration. Figures $17 A$ and $17 B$ show sand concentration and silt concentration as a function of discharge for the pumped samples collected during storm-flow events at the Monument Creek site (fig. 8). The sand-silt demarcation is taken at 63 microns $(0.063 \mathrm{~mm})$ and corresponds well to the size division between suspended sediment absent from and present in the bed (see figs. 5 and 8). Figures $17 A$ and $17 B$ show that sand concentrations in both the upper and lower Monument Creek reaches tend to increase with streamflow, but the silt concentration is essentially independent of streamflow over these storm-flow events, with an average concentration of 880 milligrams per liter $(\mathrm{mg} / \mathrm{L})$ at the upstream site and $1,062 \mathrm{mg} / \mathrm{L}$ at the downstream site.

The tendency for sand concentrations to increase with streamflow, whereas silt-and-clay concentrations are independent of streamflow, has significant implications on choosing which of the three methods for computing the suspendedsediment concentrations are most appropriate. The first Rouse method has the advantage that it does not require calibration data; however, suspended sediment must be measured because washload cannot be estimated from the bed material. Thus, one of the critical conclusions is that measurement of suspended sediment is required because of the quantity of washload in these systems. Therefore, there is no particular advantage in using this first Rouse method over the second Rouse method (with reference concentration equation calibrated with field data). At least a minimal field data set must be collected to determine washload, which also indicates that data are available for calibration of the reference concentration of larger sizes. Furthermore, because of the uncertainty in washload specification (a range of about a factor of two; figs. $17 \mathrm{~A}$ and $17 B$ ), the additional accuracy and modeling complexity of the advection-diffusion solution method is of little value. This is true because any additional accuracy in the sand concentration obtained through an advection-diffusion method will be overwhelmed by the uncertainty in washload. Therefore, of the three methods used in this study, the most reasonable approach is to use the second Rouse method for computing sand concentrations (calibrated by a few measurements or as many measurements as required to get a stable calibration) and add in washload as measured by those same field measurements. This provides the best balance between desired accuracy and the feasibility of carrying out the approach across the Fountain Creek watershed.

The Rouse method with reference concentration equation calibrated with field data was carried out for both the upper and the lower reaches of the Monument Creek site. The calibrated values and the average for the various pumped samples are shown in tables 2 and 3 for the upper and lower reaches, respectively. At the upper reach (table 2), the average calibrated gamma value was found to be 0.00347 , the median was 0.00055 , and gamma values ranged from 0.00022 to 0.015 . At the lower reach (table 3 ), the average value was found to be 0.00296 , the median was 0.00275 , and gamma values ranged from 0.0014 to 0.006 . Although this is a very broad range, it is in agreement with previous studies. For example, Harris and Wiberg (2001) found values of gamma ranging from $10^{-5}$ to $10^{-3}$, where the lower values $\left(10^{-5}\right.$ to $\left.10^{-4}\right)$ are associated with continental shelf sediments composed of fine sand and silt, and the higher values $\left(10^{-4}\right.$ to $\left.10^{-3}\right)$ are associated with sandbedded rivers and flumes. Using a very limited data set, Smith and McLean (1977) found a gamma of 0.0024 . The average value of gamma from both the upper and lower reaches of the Monument Creek site of 0.0032 is consistent with the range of literature values, especially the higher end values associated with sand-bedded rivers. The roughly similar values of gamma between the upper and lower reaches provides a good test of the methodology. The predictions of sand concentration as measured at the autosampler nozzle at both the upper and lower reaches using the calibrated average gamma from the lower reach to predict the upper reach and similarly, the upper reach to predict the lower reach (fig. 18) yields satisfactory results.

The predicted mean sand concentrations throughout the study reach using the calibrated gamma are shown in figure 19 for two of the storms in Monument Creek during the study period. In addition, because the concentration is predicted at each spatial node in the FaSTMECH model grid, it is possible to integrate these concentrations with local velocities in order to compute loads. In figure 20 the sand load computed at each model cross section is presented, whereas the total load (incorporating the measured washload material in a simple additive form) is shown in figure 21 . There is some spatial variability in the predicted load, from upstream to downstream, suggesting that the bed may scour around the middle of the reach 

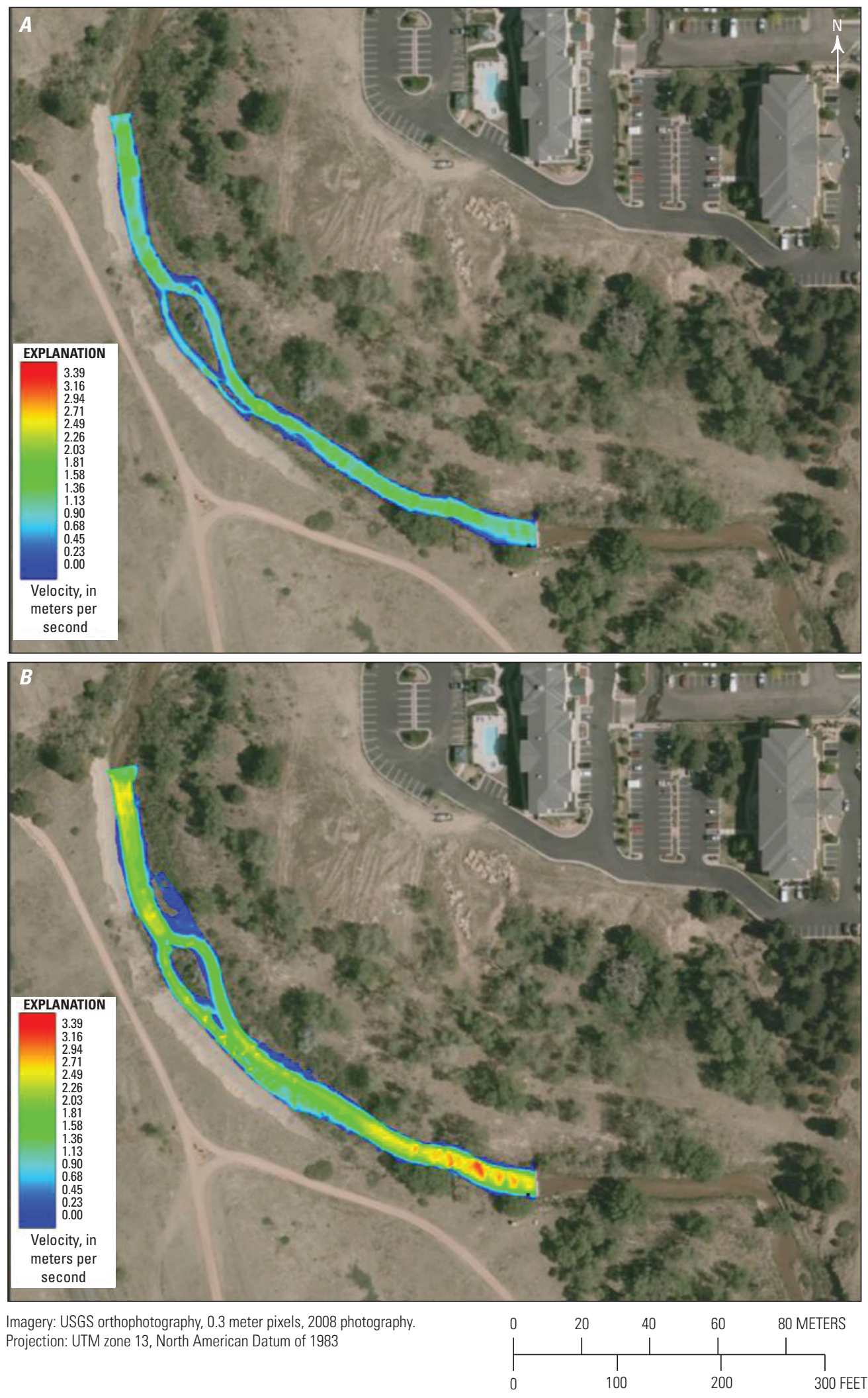

Figure 15. Predicted stream velocities in the upper Monument Creek study reach at $(A) 2.52$ cubic meters per second and $(B) 11.52$ cubic meters per second. 

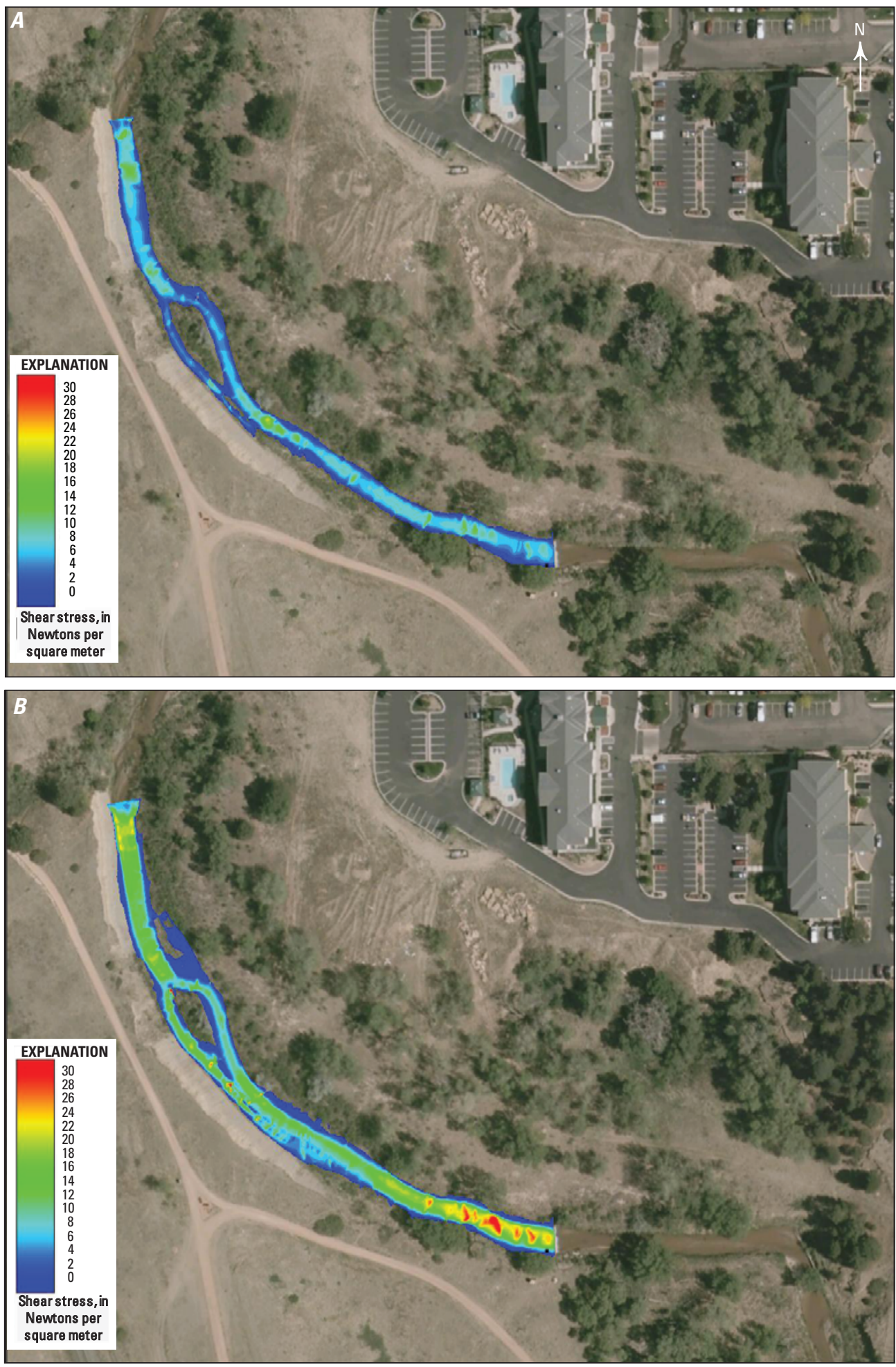

Imagery: USGS orthophotography, 0.3 meter pixels, 2008 photography. Projection: UTM zone 13, North American Datum of 1983

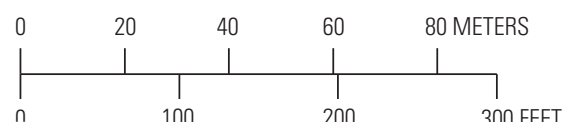

Figure 16. Predicted bed shear stress at the upper Monument Creek study reach at $(A) 2.52$ cubic meters per second and $(B) 11.52$ cubic meters per second. 


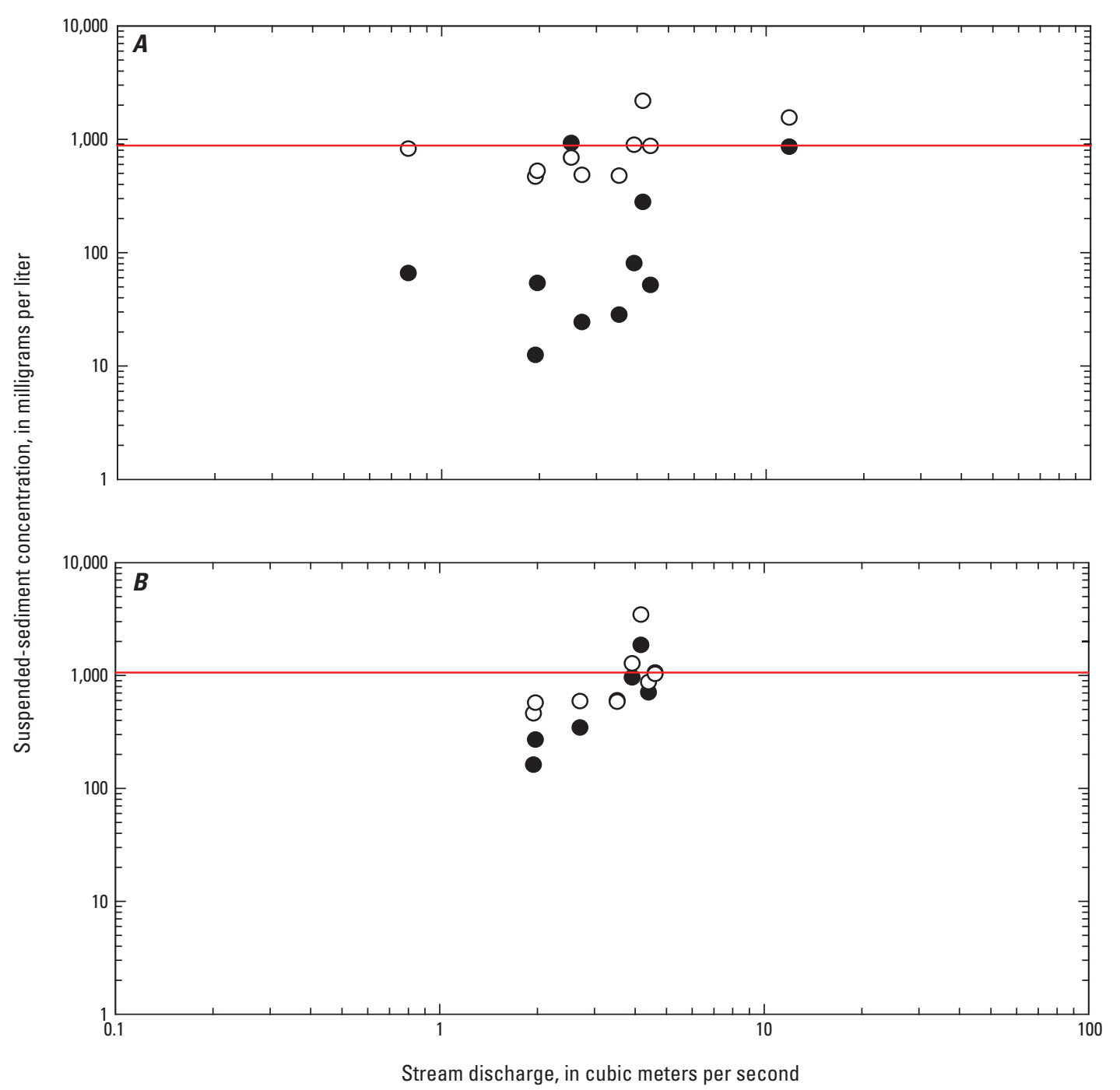

EXPLANATION

Sand concentration

Silt/clay concentration

Average silt/clay concentration

Figure 17. The measured suspended-sediment concentrations in the $(A)$ upper reach of the Monument Creek site and $(B)$ lower reach of the Monument Creek site. 
Table 2. Calculated gamma for each measured sand concentration in the upper subreach of the Monument Creek site.

$\left[\mathrm{m}^{3} / \mathrm{s}\right.$, cubic meters per second; mg/L, milligrams per liter $]$

\begin{tabular}{|c|c|c|c|c|c|c|}
\hline $\begin{array}{c}\text { Stream } \\
\text { discharge } \\
\left(\mathrm{m}^{3} / \mathrm{s}\right)\end{array}$ & $\begin{array}{l}\text { Total concentra- } \\
\text { tion (mg/L) }\end{array}$ & $\begin{array}{l}\text { Sand concentra- } \\
\text { tion (mg/L) }\end{array}$ & $\begin{array}{l}\text { Silt and clay con- } \\
\text { centration }(\mathrm{mg} / \mathrm{L})\end{array}$ & Calibrated gamma & $\begin{array}{l}\text { Predicted sand } \\
\text { concentration, } \\
\text { average gamma } \\
\text { (mg/L) }\end{array}$ & $\begin{array}{l}\text { using the aver- } \\
\text { age gamma for } \\
\text { the lower reach } \\
\text { of the Monument } \\
\text { Creek site } \\
\text { (mg/L) }\end{array}$ \\
\hline 0.79 & 872 & 64.7 & 807 & 0.015 & 14.8 & 13.0 \\
\hline 1.95 & 472 & 12.2 & 460 & 0.00023 & 176 & 153 \\
\hline 1.98 & 570 & 53 & 517 & 0.001 & 159 & 152 \\
\hline 2.52 & 1,580 & 906 & 676 & 0.0126 & 254 & 221 \\
\hline 2.72 & 498 & 23.9 & 474 & 0.00041 & 196 & 170 \\
\hline 3.54 & 496 & 27.6 & 468 & 0.00022 & 416 & 363 \\
\hline 3.94 & 957 & 79.2 & 877 & 0.00031 & 827 & 721 \\
\hline 4.19 & 2,410 & 273 & 2,140 & 0.004 & 1,320 & 1,150 \\
\hline 4.42 & 908 & 50.9 & 858 & 0.00026 & 644 & 562 \\
\hline \multirow[t]{3}{*}{11.8} & 2,360 & 843 & 1,520 & 0.00067 & 3,900 & 933 \\
\hline & & Average & 879.7 & 0.00347 & & \\
\hline & & Median & 741.5 & 0.00055 & & \\
\hline
\end{tabular}

Table 3. Calculated gamma for each measured sand concentration in the lower subreach of the Monument Creek site.

$\left[\mathrm{m}^{3} / \mathrm{s}\right.$, cubic meters per second; $\mathrm{mg} / \mathrm{L}$, milligrams per liter]

\begin{tabular}{|c|c|c|c|c|c|c|}
\hline $\begin{array}{c}\text { Stream } \\
\text { discharge } \\
\left(\mathrm{m}^{3} / \mathrm{s}\right)\end{array}$ & $\begin{array}{l}\text { Total concentra- } \\
\text { tion }(\mathrm{mg} / \mathrm{L})\end{array}$ & $\begin{array}{l}\text { Sand concentra- } \\
\text { tion }(\mathrm{mg} / \mathrm{L})\end{array}$ & $\begin{array}{l}\text { Silt and clay con- } \\
\text { centration (mg/L) }\end{array}$ & Calibrated gamma & $\begin{array}{l}\text { Predicted sand } \\
\text { concentration, } \\
\text { average gamma } \\
\text { (mg/L) }\end{array}$ & $\begin{array}{l}\text { using the average } \\
\text { gamma for the } \\
\text { upper reach of the } \\
\text { Monument Creek } \\
\text { site } \\
\text { (mg/L) }\end{array}$ \\
\hline 1.95 & 610 & 159 & 451 & 0.0029 & 163 & 190 \\
\hline 1.98 & 822 & 265 & 557 & 0.006 & 135 & 157 \\
\hline 2.72 & 928 & 345 & 583 & 0.0031 & 318 & 370 \\
\hline 3.54 & 1,170 & 583 & 583 & 0.0016 & 1,050 & 1,220 \\
\hline 3.94 & 2,200 & 954 & 1,250 & 0.0025 & 1,230 & 1,420 \\
\hline 4.19 & 5,040 & 1,830 & 3,210 & 0.0042 & 1,340 & 1,550 \\
\hline 4.42 & 1,540 & 689 & 848 & 0.0014 & 1,460 & 1,680 \\
\hline \multirow[t]{3}{*}{4.63} & 2,040 & 1,030 & 1,010 & 0.0019 & 1,550 & 1,800 \\
\hline & & Average & $1,061.5$ & 0.00296 & & \\
\hline & & Median & 715.5 & 0.00275 & & \\
\hline
\end{tabular}

Predicted sand concentration sing the average ma for the upper reach of the site

(mg/L)

157

1,550

1,800 

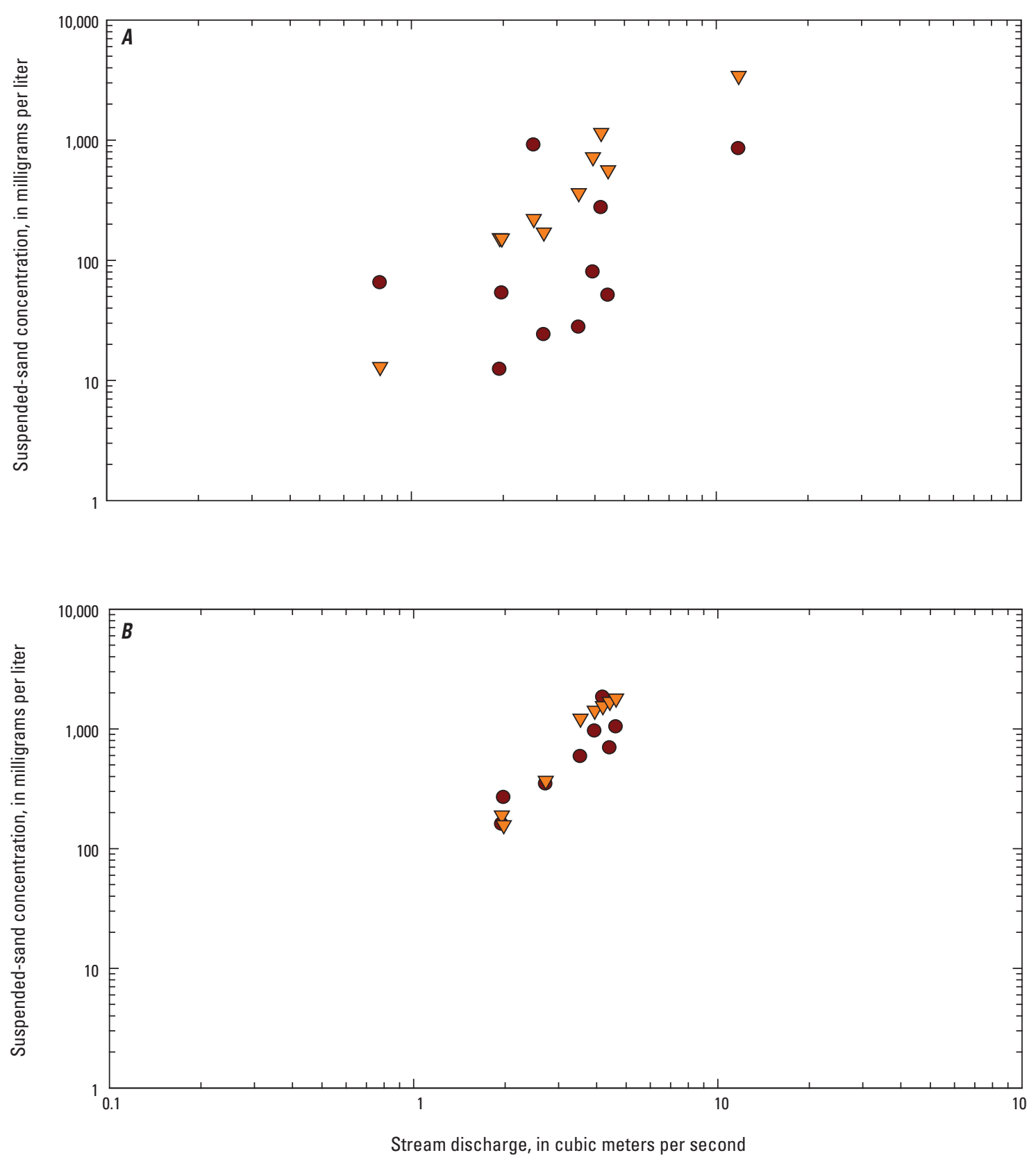

EXPLANATION

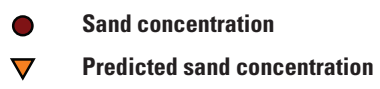

Figure 18. Predicted sand concentration at the $(A)$ upper reach of the Monument Creek site using the average calibrated gamma $(0.003)$ from the lower reach and $(B)$ lower reach of the Monument Creek site using the average calibrated gamma (0.0035) from the upper reach. 

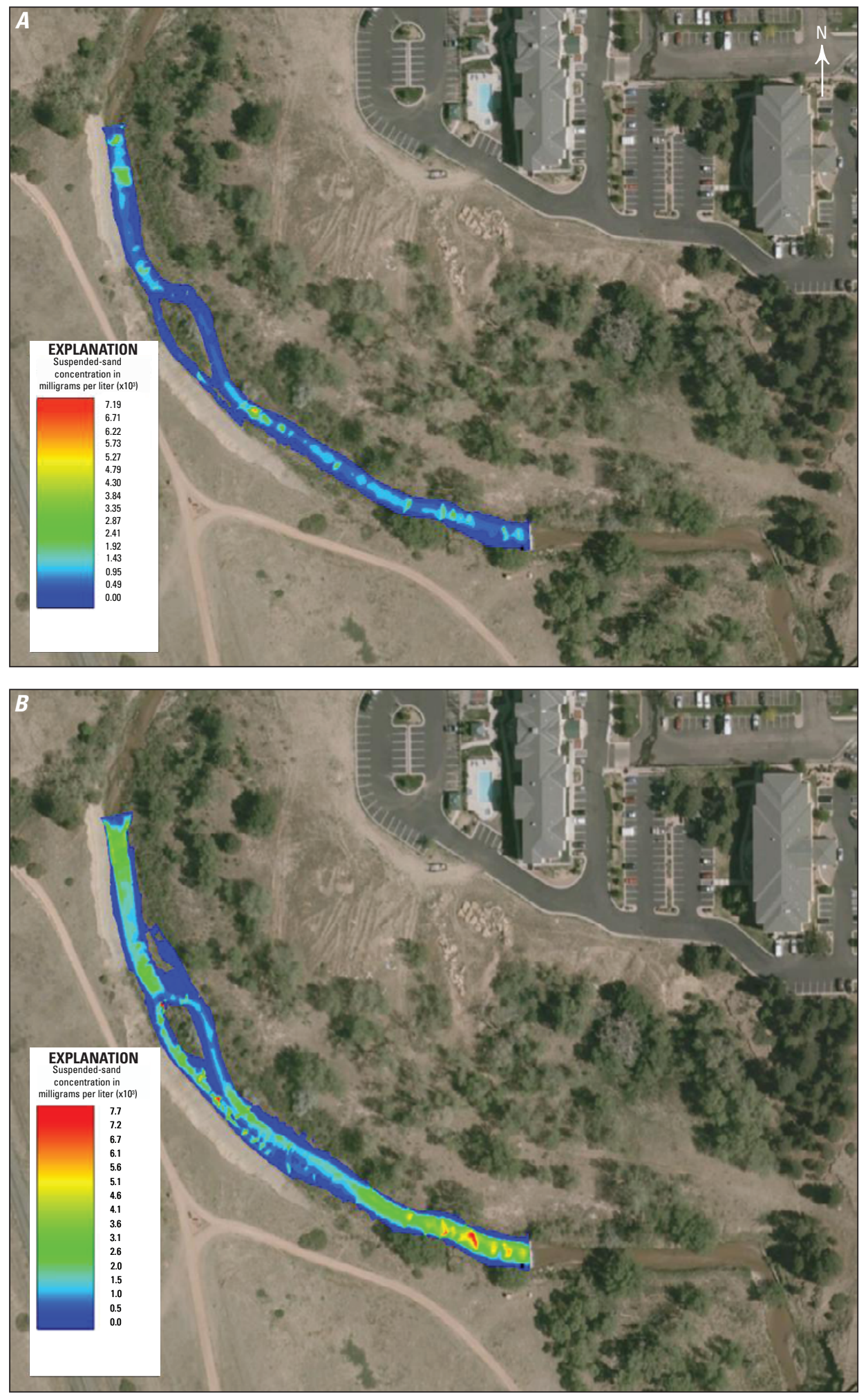

Imagery: USGS orthophotography, 0.3 meter pixels, 2008 photography. 0

Projection: UTM zone 13, North American Datum of 1983

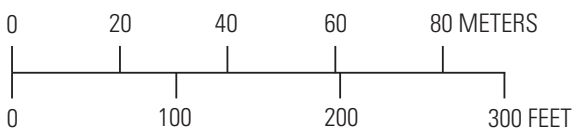

Figure 19. Mean suspended-sand concentrations at the upper Monument Creek reach for $(A)$ a storm-flow event at 2.52 cubic meters per second and $(B)$ a stormflow event at 11.52 cubic meters per second. 


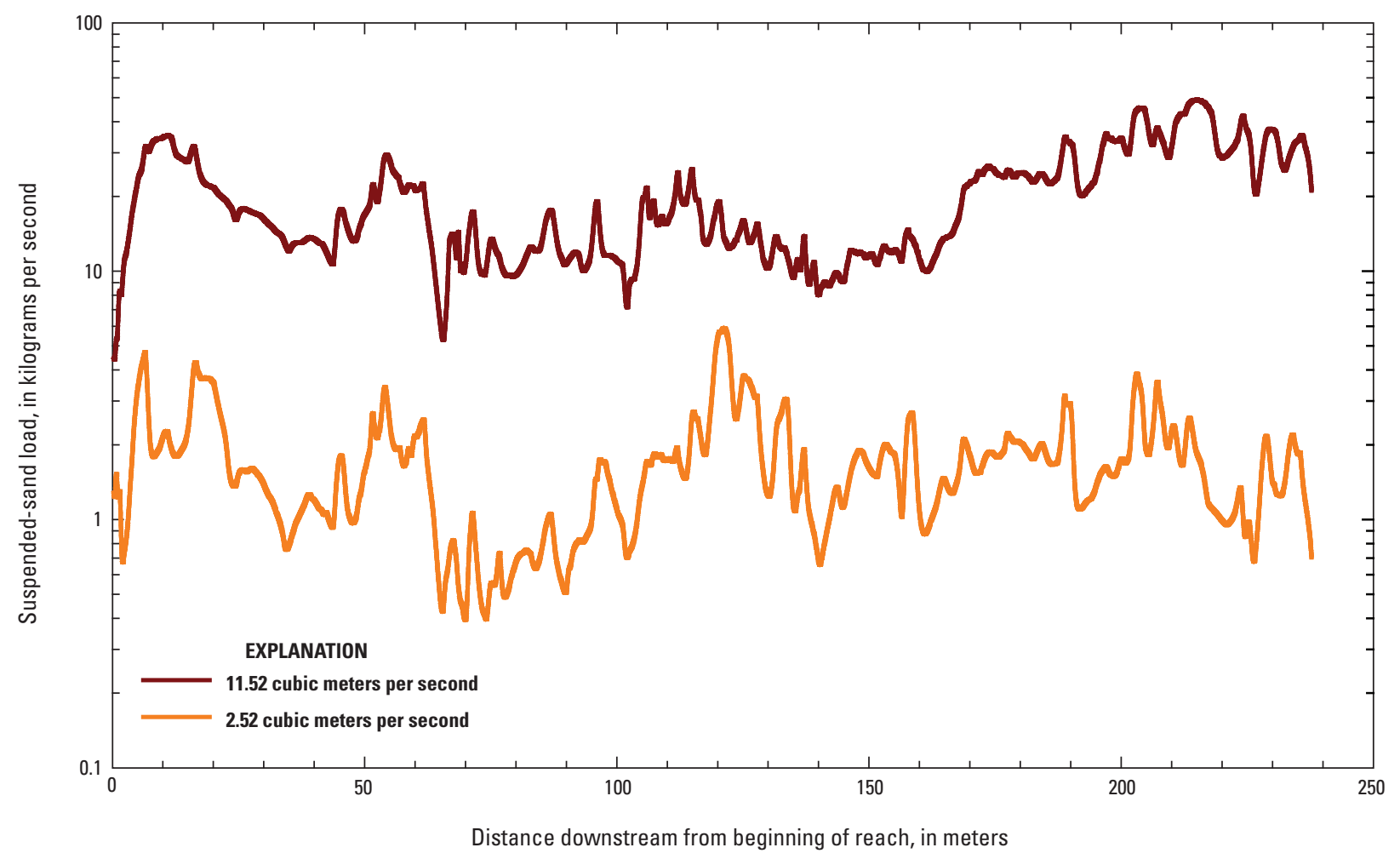

Figure 20. Suspended-sand load computed at each section in the modeling domain for the upper Monument Creek reach for two sampled storm-flow events.

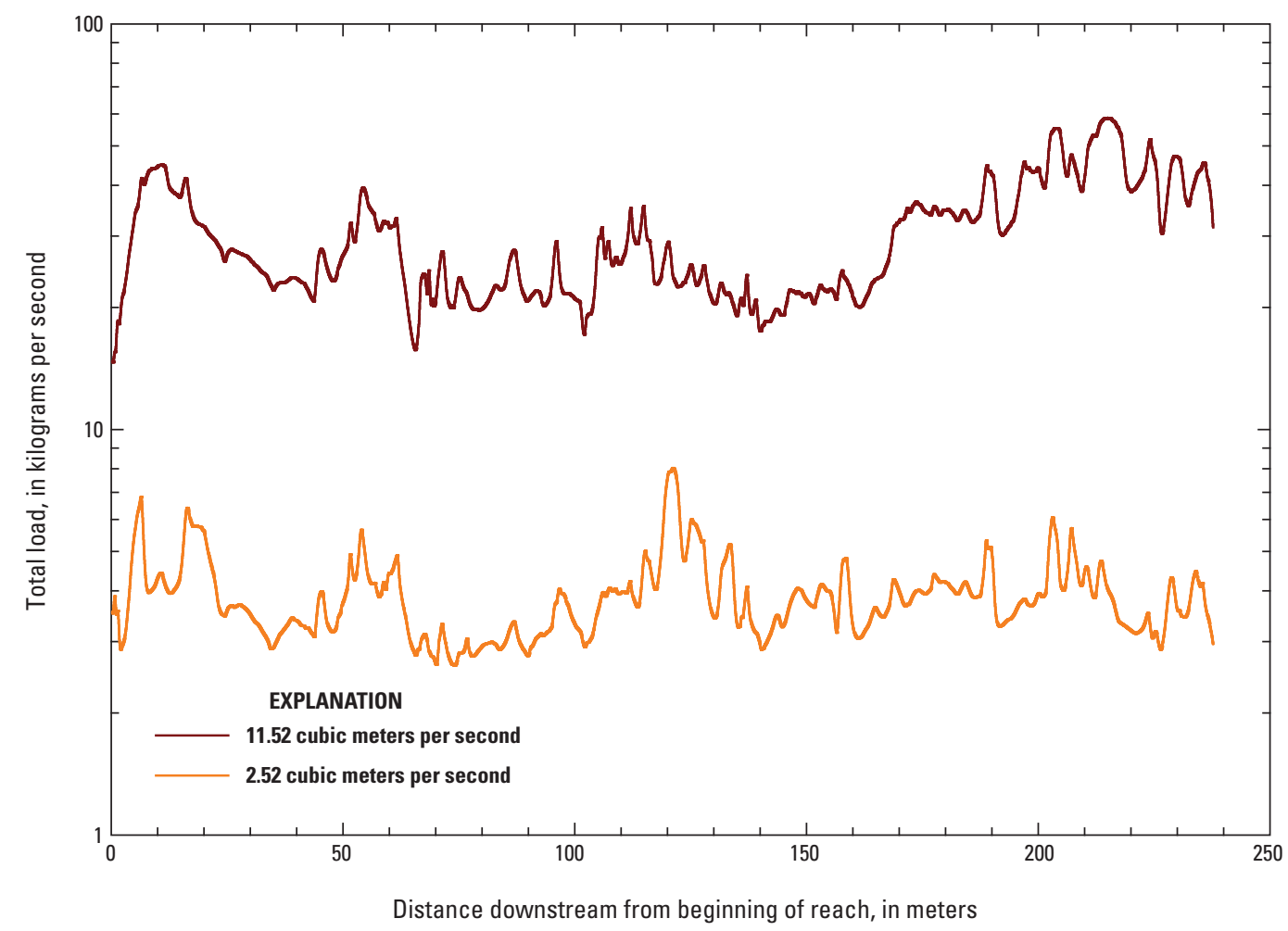

Figure 21. Total load computed at each section in the modeling domain for the upper Monument Creek reach for two sampled storm-flow events. 
during storms, but generally a simple streamwise average of these cross-sectional computed loads can be used to construct load-discharge curves.

Another test of the second Rouse method is to verify that the model predicts the distribution of size classes in suspension accurately. Figure 22 shows a comparison between the predicted and measured particle-size distributions in suspension for the two sampled storms. Given the simplicity of the method and the variability in the bed particle sizes (fig. 5), the predictions provide reasonable predictions of both the fraction and particle size.

A final test of the method is a comparison of both predicted cross-sectionally averaged suspended sand and total concentration in the upper Monument Creek site with measured total suspended-sediment concentrations collected using the Equal Width Increment (EWI) (U.S. Geological Survey, 2006) method between 2001-2008. Figure 23A shows the EWI sample suspended-sediment concentrations collected as a function of streamflow. There is an upward trend in total suspended-sediment concentration with increase in streamflow, although there is at least an order of magnitude variation in the concentration for any given value of the streamflow. The predicted sand concentrations using the Rouse method described in the "Suspended Sediment Modeling" section above, and using the calibrated gamma value for the upper Monument Creek site, are also shown for a set of variable particle-size fractions of the bed sediments (fig. 23B) based on five particle-size distributions (1-5 in fig. 23A). The predicted sand concentrations fall within the higher end of the range of measured total suspended-sediment concentrations using the average particle-size distribution calculated from all 10 of the measured particle-size samples at the upper Monument Creek reach (distribution 1 in fig. 23). The prediction was for sand concentration, and the EWI suspended-sediment sample measurements report total concentration, and it is expected that the prediction will fall within the lower end of the measured range of total concentrations for each streamflow because the silt-and-clay fraction is not predicted. To investigate the sensitivity of the calculation to the measured particle size, three other particle-size distributions (distributions 2-4 in fig. 23A) were calculated as follows: (2) the average particle-size distribution calculated from all nine main channel samples (the one sample collected on the top of the island in the upper Monument Creek reach that had a much higher percentage of smaller particle sizes compared with the other nine samples collected in the main channel was not used to calculate the average), (3) the coarsest sample of the 10 collected bed samples, and (4) the finest grain-size sample of the 10 collected bed samples. Using (2) and (3) described above results in only a small change to the particle-size distribution used to predict the suspended-sand concentration (fig. $23 B$ ) but results in predicted suspended-sand concentrations that fall within the lower range of the measured concentrations as would be expected. Using (3), the finest fraction, results in prediction of unrealistically high sand concentrations. The prediction is sensitive to the specification of the particle-size distribution of the bed material and suggests that care should be taken to collect bed material samples that are representative of the active bed during the likely flow events to be simulated. A final calculation (distribution 5 in fig. 23) was made by predicting the suspended-sand concentration using the average particlesize distribution of the collected main channel sediments and adding the average measured silt-and-clay concentration as a constant value throughout the water column. The resulting predicted total suspended-sediment concentration falls within the bounds of the measured data above a streamflow of $2 \mathrm{~m}^{3} / \mathrm{s}$, but approaches the value of the constant silt-and-clay concentration below $2 \mathrm{~m}^{3} / \mathrm{s}$. An inspection of the streamflow history during the study (fig. 8) shows that base-flow conditions generally exist at less than 1 or $2 \mathrm{~m}^{3} / \mathrm{s}$. Assuming that the source of the silt-and-clay fraction of the total suspended-sediment load is associated with overland flow from rainfall events or access to fine sediment deposited during a previous high-flow event on the floodplain or high banks, some accommodation should be made for the lack of suspended silt-and-clay during base-flow conditions.

\section{Implications for Future Work}

Based on what has been learned from this preliminary study, the recommended procedure for using a model-based methodology to estimate suspended-sediment loads in the Fountain Creek watershed is a calibrated Rouse method in conjunction with the FaSTMECH flow model. Detailed surveys would be made at each field site and a single autosampler would be installed. Additionally, bed-material samples would be collected throughout the reach (approximately 10 samples depending on observed spatial variability). If there is a streamgage nearby, this could be used for stage-discharge data, otherwise, a temporary pressure transducer and some streamflow measurements would be required. The autosampler would be used to collect suspended-sediment samples. The data from the suspended-sediment samples would be used to calibrate the reference concentration at the location of the sampler, and then that value would be used in the model to estimate suspended-sediment loads through the reach. These estimates could also be used to develop load-discharge curves. [A simple streamwise average of these cross-sectional computed loads should be used to construct load-discharge curves. Fine-tuning a curve for the suspended silt-clay fraction would benefit from a more complete set of samples collected through the autosampler over a wider range of streamflows.] Washload would be estimated as a function of streamflow (if warranted) based on the data from samples collected by the autosampler used to calibrate the reference concentrations for sand. If this basic methodology was followed at most significant junctions in the watershed, an overall view of the sources of sediment and potential effects of focused remediation could be developed. 

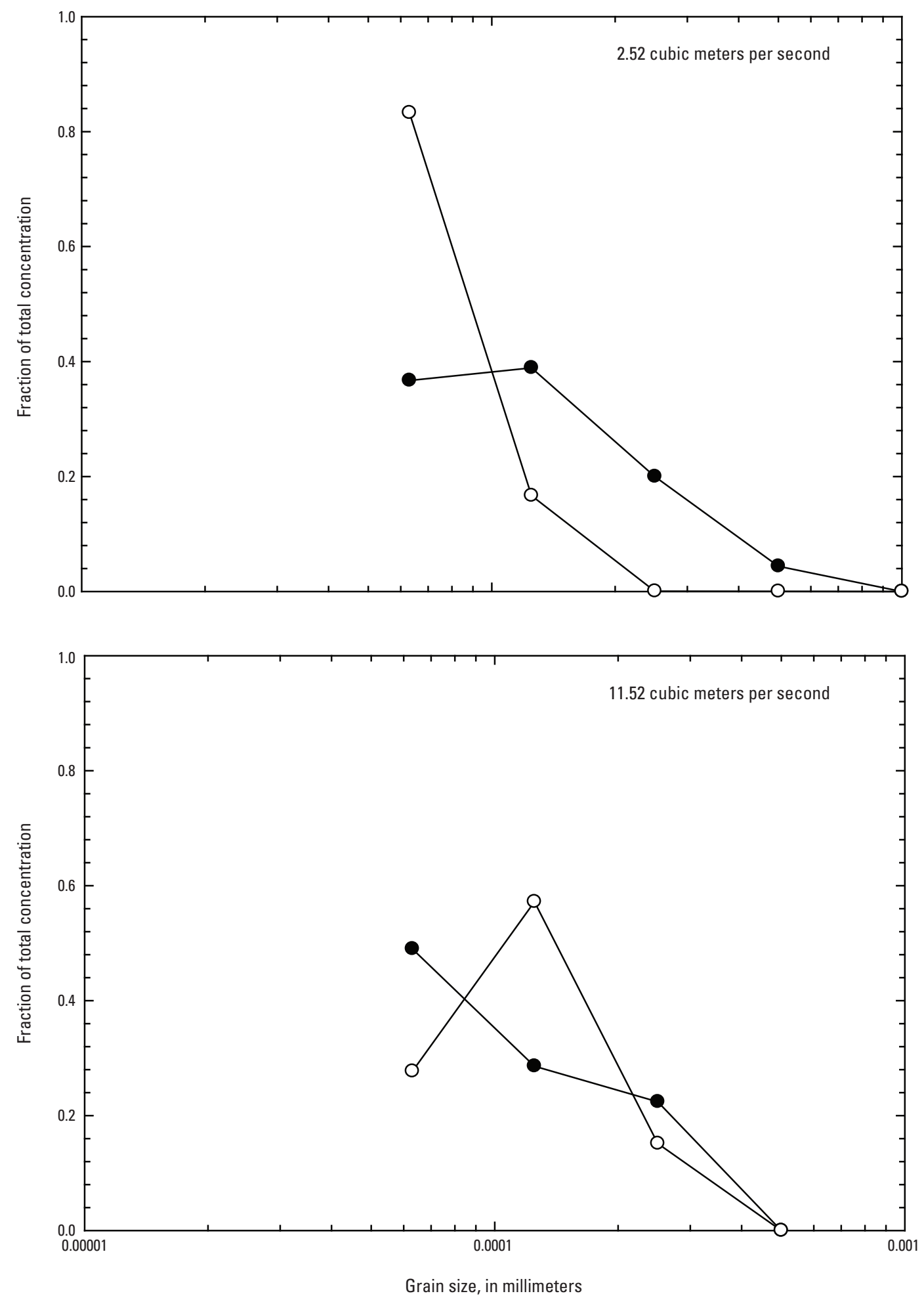

EXPLANATION

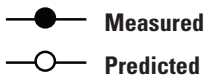

Figure 22. The measured and predicted sand fraction as a function of particle size for each of two sampled storm events. 


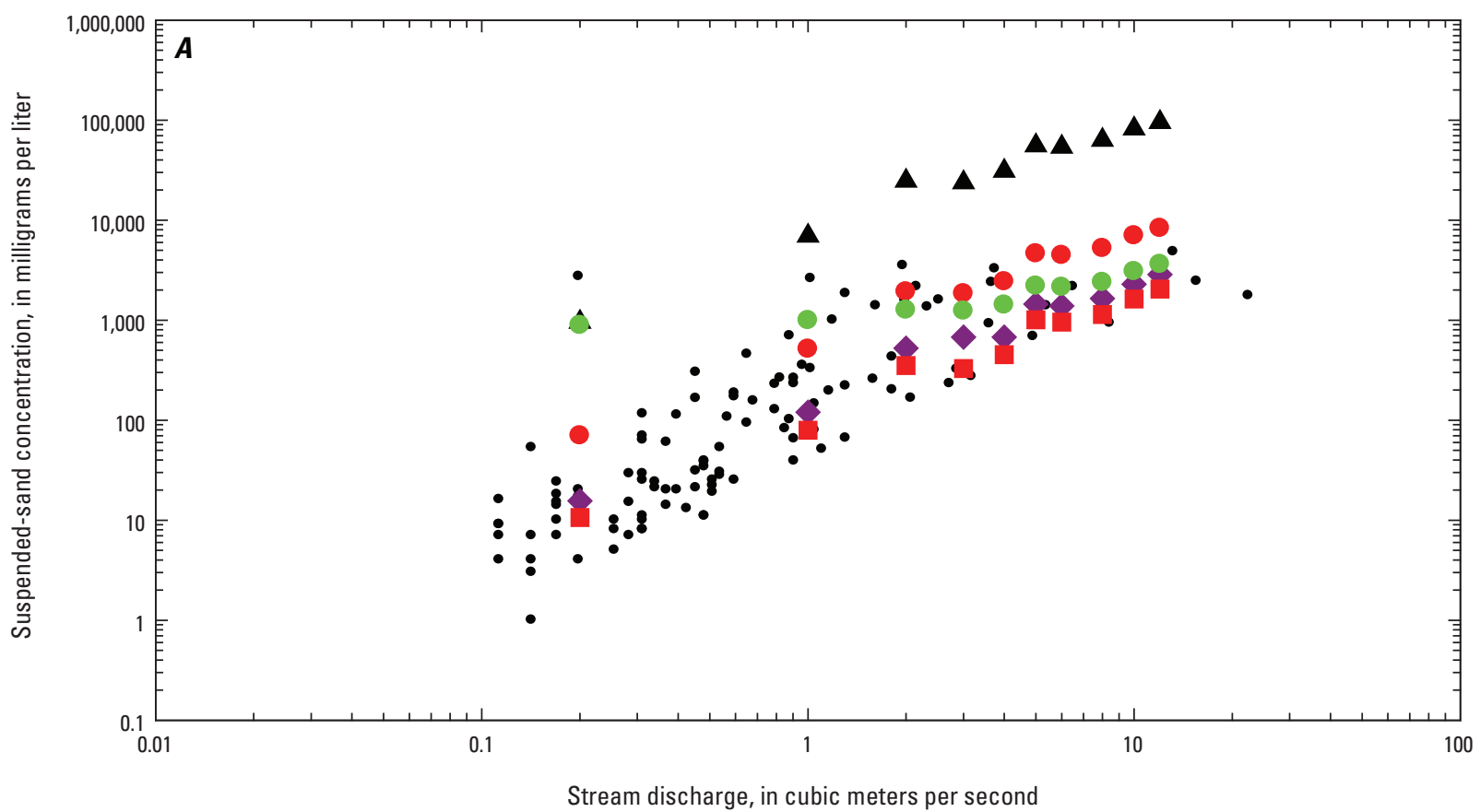

EXPLANATION

- Equal-width-increment suspended-sediment concentration

(1) the mean particle-size distribution of all $\mathbf{1 0}$ measured bed-sediment samples

(2) the mean particle-size distribution of all nine main channel bed-sediment samples

(3) the coarsest particle-size distribution

- (4) the finest particle-size distribution

(5) the particle-size distribution of the nine main channel bed-sediment samples and adding a constant ( 844.8 milligrams per liter) silt-and-clay fraction based on the average silt-and-clay fraction measured.

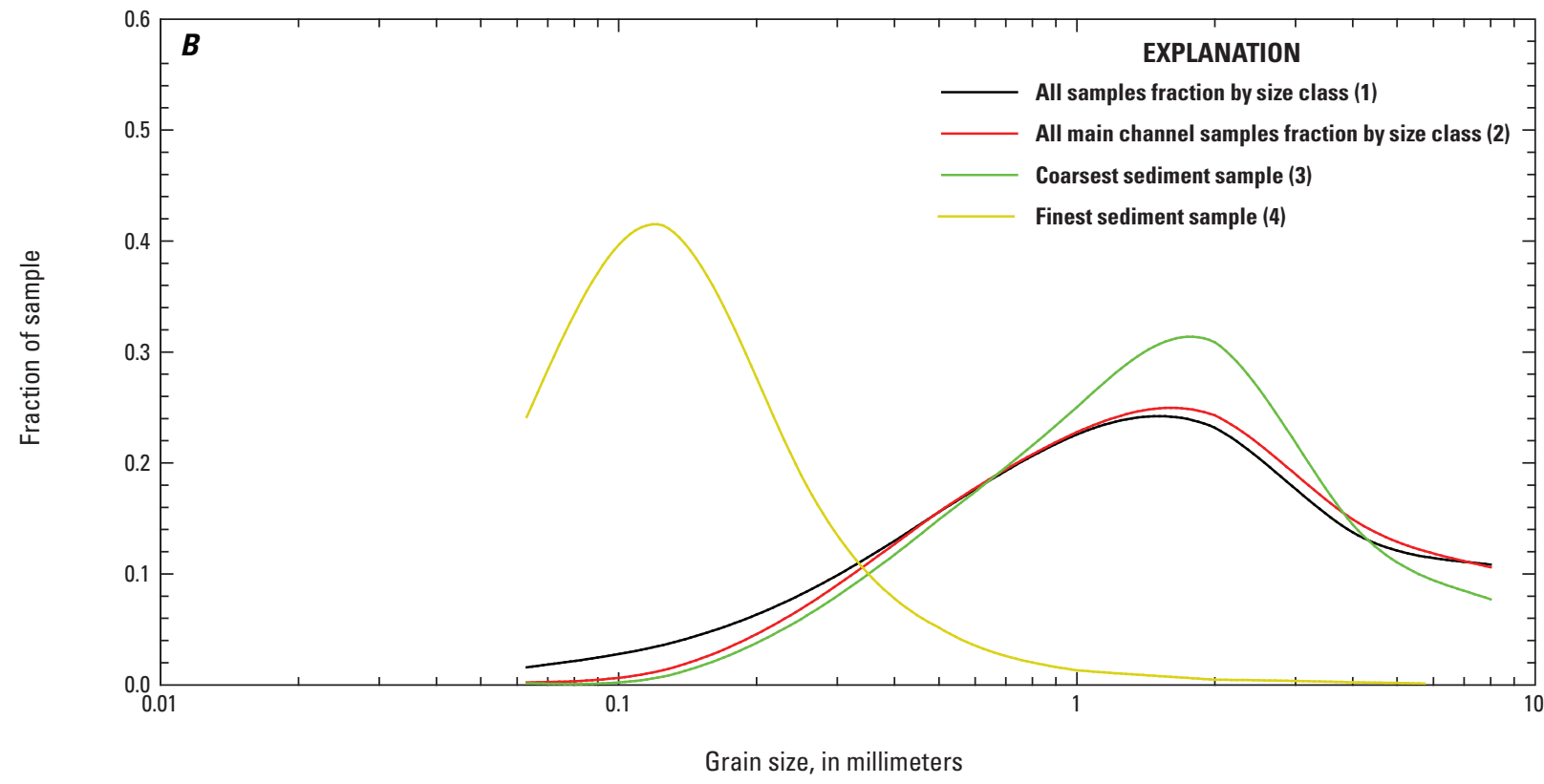

Figure 23. (A) The measured total suspended-sediment concentration using the Equal Width Increment (EWI) method for all samples collected at the upper Monument Creek reach from 2001-08 and the mean predicted suspendedsand concentration (particle-size distributions $1-5)$, and $(B)$ Particle-size fractions for the predicted particle-size distributions $1-4$ described in $(A)$. 


\section{Summary}

In 1998, the USGS began a small-scale pilot study to evaluate the effectiveness of a computational model of flow and suspended-sediment transport for predicting suspendedsediment concentrations and loads in the Fountain Creek watershed in Colorado. This study was conducted in cooperation with Pikes Peak Area Council of Governments, Colorado Water Conservation Board, Colorado Springs City Engineering, and the Lower Arkansas Valley Water Conservancy District. The Fountain Creek Corridor Restoration Master Plan identified erosion and sedimentation damage as key problems within the basin, and a recommendation for management of the basin from the plan is to establish measurable criteria to determine if progress in reducing erosion and sedimentation damage is being made. This report describes efforts to develop, calibrate, and validate a multidimensional model as an inexpensive tool to predict suspended-sediment loads at various locations within the Fountain Creek watershed in southeastern Colorado. Two locations in the Fountain Creek watershed, Monument Creek above Woodmen Road and Sand Creek near the mouth, were selected as study sites.

Suspended-sediment samples were collected using automatic-pumping samplers located at USGS gages in each study reach and at the downstream end of each study reach. Stage was measured at USGS gages, and pressure transducers were located in the study reaches. The geometry of the study reaches were surveyed to a horizontal accuracy of $\pm 1 \mathrm{~cm}$ and a vertical accuracy of $\pm 2 \mathrm{~cm}$ using RTK GPS equipment.

The USGS MultiDimensional Surface-Water Modeling System was used to evaluate cost of development and accuracy of three models: (1) Rouse method with Smith/McLean reference concentration, (2) Rouse method with referenceconcentration equation calibrated with field data, and (3) advection-diffusion solution.

Bed-sediment samples were collected to characterize the size distribution and spatial variation of particle sizes of sediment on the beds in the two study reaches. These data were used to develop and (or) calibrate the flow and sediment transport models.

Bed-sediment particle sizes at both locations were dominated by sand- and gravel-size particles. Changes in bed geometry as a result of scour and fill of bed sediments of \pm 0.3 $\mathrm{m}$ in the Sand Creek reach during storm flows altered the initial boundary conditions of the model. Subsequently, calibration of the flow model was not possible; therefore, no further analyses were attempted for this reach. Attempts to develop a model for the Sand Creek site and (or) similar sites may necessitate pre- and post-storm channel surveys given the dynamic nature of the bed and the implications for model calibration. At the Monument Creek site, the presence of a grade-control structure near the center of the study reach necessitated the splitting of the reach into two subreaches, an upper and lower reach.

At the Monument Creek site, a portion of the suspended particles were finer than particle sizes found in bed sediments.
Therefore, the Rouse method with Smith/McLean reference concentration cannot accurately predict the total suspendedsediment concentration based only on bed-material sizes and local bed shear stress. Therefore, because a minimal amount of field data would be required to determine washload, the Rouse method with reference-concentration equation calibrated with field data would have some predictive power. Also, the additional accuracy and model complexity of the advectiondiffusion model is of little value due to the uncertainty in the washload concentration. Data collected in the lower reach were used to validate the model developed from data collected in the upper reach. Results of model predictions of flow velocity and sediment transport are compared to velocity and sediment data for two storm streamflows, $2.52 \mathrm{~m}^{3} / \mathrm{s}$ and 11.52 $\mathrm{m}^{3} / \mathrm{s}$, for which suspended-sediment data were collected.

\section{References Cited}

Bent, G.C., Gray, J.R., Smith, K.P., and Glysson, G.D., 2001, A synopsis of technical issues for monitoring sediment in highway and urban runoff: U.S. Geological Survey OpenFile Report 00-497, 62 p., available at http://pubs.usgs.gov/ of/2000/ofr00-497/pdf/ofr00497.pdf.

Buchanan, T.J., and Somers, W.P., 1969, Discharge measurements at gaging stations: U.S. Geological Survey Techniques of Water-Resources Investigations, book 3, chap. A8, 65 p.

Carter, R.W., and Davidian, J., 1968, General procedure for gaging streams: U.S. Geological Survey Techniques of Water-Resources Investigations, book 3, chap. A6, 13 p.

Conaway, J.S., and Moran, E.H., 2004, Development and calibration of a two-dimensional hydrodynamic model of the Tanana River near Tok, Alaska: U.S. Geological Survey Open-File Report 2004-1225, 13 p., available at http://pubs.usgs.gov/of/2004/1225/.

Dietrich, W.E., 1982, Settling velocity of natural particles: Water Resources Research, v. 18, no. 6, p. 1615-1626.

Doesken, N.J., Pielke, R.A., Sr., and Bliss, O.A.P., 2003, Learn about the climate of Colorado: Colorado State University Web site, accessed June 9, 2011, at http://climate.colostate.edu/climateofcolorado.php.

Dunne, Thomas, and Leopold, L.B., 1978, Water in environmental planning: New York, Freeman, 818 p.

Edwards, T.K., and Glysson, G.D., 1999, Field measurements of fluvial sediment: U.S. Geological Survey Techniques of Water-Resources Investigations, book 3, chap. C2, 89 p.

Fischer, H.B., List, E.J., Koh, R.C.Y., Imberger, J., and Brooks, N.H., 1979, Mixing in inland and coastal waters: New York, Academic Press, 483 p. 
Fountain Creek Watershed Flood Control and Greenway District, 2011, Fountain Creek Corridor Restoration Master Plan: fountain-crk.org, accessed April 10, 2014, at http://www.fountain-crk.org/files/REPORTS/corr_rest_masterplan101811_final.pdf.

Garcia, M., and Parker, G., 1991, Entrainment of bed sediment into suspension: Journal of Hydraulic Engineering, ASCE, v. $117(\mathrm{~N} 4)$, p. 414-435.

Guy, H.P., 1969, Laboratory theory and methods for sediment analysis: U.S. Geological Survey Techniques of WaterResources Investigations, book 5, chap. C1, 64 p.

Harris, C.K., and Wiberg, P.L., 2001, A two-dimensional, time-dependent model of suspended sediment transport and bed reworking for continental shelves: Computers and Geosciences, v. 27, p. 675-690.

Helsel, D.R., and Hirsch, R.M., 1992, Statistical methods in water resources: New York, Elsevier, 522 p.

Kinzel, P.J., Nelson, J.M., and Heckman, A.K., 2009, Response of sandhill crane (Grus Canadensis) riverine roosting habitat to changes in stage and sandbar morphology: River Research and Applications, v. 25, p. 135-152, available at $h t t p: / / w w w 3$.interscience.wiley.com/cgi-bin/ fulltext/119876487/PDFSTART/.

Knighton, D., 1998, Fluvial forms and processes: a new perspective: New York, Oxford University Press, Inc., 383 p.

Larsen, L.S., 1981, Soil survey of El Paso County area, Colorado: Washington D.C., United States Department of Agriculture Soil Conservation Service, 212 p.

Leopold, L.B., Wolman, M.G., and Miller, J.P., 1964, Fluvial processes in geomorphology: San Francisco, W.H. Freeman Press, $522 \mathrm{p}$.

Logan, B.L., McDonald, R.R., Nelson, J.M., Kinzel, P.J., and Barton, G.J., 2011, Use of multidimensional modeling to evaluate a channel restoration design for the Kootenai River, Idaho: U.S. Geological Survey Scientific Investigations Report 2010-5213, 74 p.

Mau, D.P., Stogner, R.W., Sr., and Edelmann, Patrick, 2007, Characterization of stormflows and wastewater treatmentplant effluent discharges on water quality, suspended sediment, and stream morphology for Fountain and Monument Creek watersheds, Colorado, 1981-2006: U.S. Geological Survey Scientific Investigations Report 2007-5104, 76 p.

McDonald, R.R., Bennett, J.P., and Nelson, J.M., 2001, The USGS multi-dimensional surface water modeling system: Proceedings of the Seventh Interagency Sedimentation Conference, March 25 to 29, 2001, Reno, Nev., v. 1, p. I-161-167.
McDonald, R.R., Nelson, J.M., Kinzel, P.J., and Conaway, J.S., 2006, Modeling surface-water flow and sediment mobility with the multi-dimensional surface-water modeling system: U.S. Geological Survey Fact Sheet 2005-3078, 6 p.

McDonald, R., Nelson, J., Paragamian, V., and Barton, G., 2010, Modeling the effect of flow and sediment transport on white sturgeon spawning habitat in the Kootenai River, Idaho: Journal of Hydraulic Engineering, v. 136, no. 12, p. 1077-1092.

McLean, S.R., 1992, On the calculation of suspended load for noncohesive sediments: Journal of Geophysical Research, v. 97(C4), p. 5759-5770.

Meister, Matt, 2010, Colorado's terrain: Where is that? Descriptions of geographic features in Colorado and how they influence our weather: KRDO.com, accessed June 9, 2011, at http://www.krdo.com/weather/23135825/detail. html.

Middleton, R.R., and Southard, J.B., eds., 1984, Mechanics of sediment movement: Tulsa, Okla., SEPM Short Course No. 3, 401 p.

Nelson, J.M., Bennett, J.P., and Wiele, S.M., 2003, Flow and sediment transport modeling, in Kondolf, G.M., and Piegay, H., eds., Tools in fluvial geomorphology: England, Wiley, p. 539-576.

Nelson, J.M., and McDonald, R.R., 1997, Mechanics and modeling of flow and bed evolution in lateral separation eddies: U.S. Geological Survey, Grand Canyon Monitoring and Research Center, Glen Canyon Environmental Studies Report, 69 p.

Nikuradse, Johann, 1933, Laws of flow in rough pipes, in National Advisory Commission for Aeronautics Technical Memo 1292 (1950): Washington, D.C., 62 p.

Ritter, D.F., Kochel, R.C., and Miller, J.R., 2002, Process geomorphology: New York, McGraw-Hill Company, 560 p.

Smith, J.D., and McLean, S.R., 1977, Spatially averaged flow over a wavy surface: Journal of Geophysical Research, v. 82 , no. 12 , p. $1735-1746$.

Stogner, R.W., Sr., 2000, Trends in precipitation and streamflow and changes in stream morphology in the Fountain Creek watershed, Colorado, 1939-99: U.S. Geological Survey Water-Resources Investigations Report 00-4130, 43 p.

Trimble Navigation Limited, 1998, Survey controller field guide, ver 7.0: Sunnydale, Calif., Trimble Navigation Limited. 
Trimble Navigation Limited, 2009, Trimble R8 GNSS

Receiver data sheet: Sunnydale, Calif., Trimble Navigation

Limited, accessed August 4, 2011, at http://trl.trimble.com/ docushare/dsweb/Get/Document-140079/022543-079J_ TrimbleR8GNSS_DS_1109_LR.pdf.

U.S. Army Corps of Engineers, 2009, Fountain Creek watershed management plan: U.S. Army Corps of Engineers, accessed April 3, 2012, at http://www.fountain-crk.org/files/ REPORTS/aco_final_Jan09.pdf.

U.S. Census Bureau, 2010a, Colorado-Population of counties by decennial census, 1900 to 1990: U.S. Bureau of Census, accessed January 13, 2010, at http://www.census. gov/population/cencounts/co190090.txt.

U.S. Census Bureau, 2010b, Profile of general demographic characteristics, 2000: U.S. Bureau of Census, accessed April 10, 2012, at http://factfinder2.census.gov/faces/tableservices/jsf/pages/productview.xhtml?src $=b k m k$.

U.S. Geological Survey, 2006, Collection of water samples, ver. 2.0: U.S. Geological Survey Techniques of WaterResources Investigations, book 9, chap. A4, accessed August 31, 2010, at http://pubs.water.usgs.gov/twri9A.

U.S. Geological Survey, 2012a, National Water Information System, accessed April 5, 2012, at http://waterdata.usgs. gov/nwisweb/local/nwis_host/nwisdcolka/local/site_text/ site_info/txt07103970.htm.

U.S. Geological Survey, 2012b, National Water Information System, accessed April 5, 2012, at http://waterdata.usgs. gov/nwis/nwisman/?site_no $=07105600 \&$ agency_cd $=U S G S$.

von Guerard, Paul, 1989, Suspended sediment and sedimentsource areas in the Fountain Creek drainage basin upstream from Widefield, southeastern Colorado: U.S. Geological Survey Water Resources-Investigations Report 88-4136, 36 p.

Whiting, P. J., and Dietrich, W.E, 1991, Convective accelerations and boundary shear stress over a channel bar: Water Resources Research, v. 27, no.5, p. 783-796.

Winterstein, T.A., 1986, Effects of nozzle orientation on sediment sampling, in Proceedings of the Federal Interagency Sedimentation Conference, 4th, Las Vegas, Nev., March 24-27, 1986: Las Vegas, Nev., Subcommittee on Sedimentation, p. 1-20-1-28.
Publishing support provided by:

Denver Publishing Service Center

For more information concerning this publication, contact: Director, USGS Colorado Water Science Center Box 25046, Mail Stop 415

Denver, CO 80225

(303) 236-4882

Or visit the Colorado Water Science Center Web site at: http://co.water.usgs.gov/ 


\section{ख़}

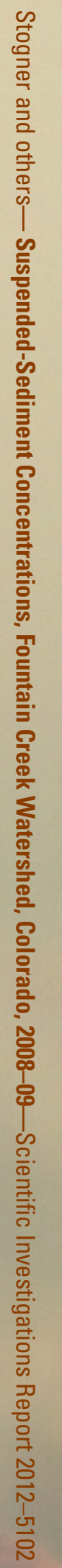

